\title{
"THE CASHTRO HOP PROJECT" \\ HIP HOP MUSIC AND AN EXPLORATION OF \\ THE CONSTRUCTION OF ARTISTIC SELF-IDENTITY
}

by

Christopher Joseph Cachia

\author{
A Project \\ presented to Ryerson and York Universities \\ in partial fulfillment of the \\ requirements for the degree of \\ Master of Arts \\ in the Program of \\ Communication and Culture
}

Toronto, Ontario, Canada, 2006

(1) Chris Cachia 2006 


\section{Declaration}

I hereby declare that I am the sole author of this project.

I authorize Ryerson University to lend this project to other institutions or individuals for the purpose of scholarly research.

I further authorize Ryerson University to reproduce this project, in total or in part, at the request of other institutions or individuals for the purpose of scholarly research. 


\begin{abstract}
While Hip Hop culture has regularly been legitimized within academia as a social phenomenon worthy of scholarly attention (witness the growing number of studies and disciplines now taking Hip Hop as object for analysis), this is the first Hip Hop-themed project being completed within the academy. Indeed, academic and critical considerations of one's own Hip Hop-based musical production is a novel venture; this project, as a fusion of theory with practice, has thus been undertaken so as to occupy that gap. The paper's specific concern is with how (independent) Hip Hop recording artists work to construct their own selves and identity (as formed primarily through lyrical content); the aim here is to explore Hip Hop music and the construction of artistic self-presentation. I therefore went about the task of creating my own album - my own Hip Hopthemed musical product - in order to place myself in the unique position to examine it critically as cultural artifact, as well as to write commentary and (self-)analyses concerning various aspects of (my) identity formation. The ensuing outlined tripartite theoretical framework is to serve as a model through which other rappers/academics may think about, discuss, and analyze their own musical output, their own identities, their own selves.
\end{abstract}




\section{ACKNOWLeDGMENTS}

An undertaking of this size could not be completed without the generous support and outright help of others; I would therefore like to acknowledge those individuals who have gone beyond the call of duty to encourage and make possible this project. To my parents, for helping fund my education - but more for their constant love, guidance, and support; you are my heroes. To Charlie McEvoy, for all his assistance with the recording of my album - but more for the sharing of his home and family; you have been my friend for nearly twenty years, and I am proud of all your accomplishments. To Catherine Cachia, for my album's wonderful cover art - but more for her overall creative energy, listening ear, and kind heart; I am blessed to have a sister (and friend) like you. To Jinhee Won, for the amazing website - but more for her always being there to share food, laughter, and dreams; you are one of my best friends and I cherish our relationship always. To Jennifer Brayton, for serving as my work's supervisor - but more for her constant interest, sage counsel, and blossoming friendship; you are an inspiration. To the rest of my supervisory committee, Steve Bailey and Michael Murphy, thanks for lending your support. To all who encouraged my work, especially Daniel Zuccala (the closest to a brother I have had), Ryan O'Connor, Tok Olaleye, and Neil Thompson, it means a great deal. Finally, though at times I have been timid, unsure, or even afraid, here's to me - for not giving-up. 


\section{Table of Contents}

Introduction

Project Description and Processes

Hip Hop's Cultural History

Norms of Hip Hop Culture and Its Traditions of Musical Production

Theoretical Framework I -

Presentation and the Self: On the Work of Erving Goffman

Theoretical Framework II -

(Gangsta) Rap Music and The Poetics of Identity: The Work of Adam Krims

Theoretical Framework III -

Rap and Race: On Tricia Rose and Bakari Kitwana

Commentaries

(Self-)Analyses

Conclusion

Appendices

Appendix 1: The Hiphop Declaration of Peace

Appendix 2: Ice Cube Lyrical Transcript 


\section{"THE CASHTRO HOP PROJECT"}

\section{Hip Hop Music and An Exploration of The Construction of Artistic Self-Identity}

It is probably no mere historical accident that the word person, in its first meaning, is a mask. It is rather a recognition of the fact that everyone is always and everywhere, more or less consciously, playing a role... It is in these roles that we know each other, it is in these roles that we know ourselves.

- Robert Ezra Park, Race and Culture

It is arguable that Hip-Hop culture, with its focus on "realness" and claims of cultural ownership, foregrounds identity with an explicitness well-nigh unprecedented even in the ethnically and gender-loaded world of popular musics.

- Adam Krims, Rap Music and the Poetics of Identity

\section{INTRODUCTION}

As communication and cultural studies has steadily garnered greater academic interest and support, so too has the serious study of Hip Hop culture. Beginning with David Toop's now seminal 1984 work, The Rap Attack: African Jive to New York Hip Hop, an influx of volumes have been produced working to specifically and seriously analyze Hip-Hop culture and its multifarious aspects, including commentaries and analyses focused on the culture's unique styles of dress, speech, art, dance, and music. To be sure, studies have attempted to trace the history and impact of Hip Hop within Cuba (see Fernandes, 2003), the Czech Republic (see Bertram, 2003), France (see Bluher, 2001; Liu, 1997; Mitchell, 2000; Orlando, 2003; Prevos, 1998; Shapiro, 2004), Germany (see Cheeseman, 1998; Elflein, 1998; El-Tayeb, 2003), Italy (see Mitchell, 2000), New Zealand (see Mitchell, 2000), Tanzania and Malawi (see Fenn, 2000), as well as within broader Asian (see Dawson, 2002) and European (see Androutsopoulos, 2003) contexts. As well, there has been a growing amount of theses work at both the master's and 
doctoral levels analyzing Hip Hop culture (see Anderson, 2004; Barnwell, 2004; Cutler, 2002; Hendershott, 2004; Hochtritt; 2004; LaBennett, 2002; McLellan, 2002; Osumare, 1990; Poteet, 2002; Rose, 1993; Rutherford, 2001; Smith, 2003; Somers-Willett, 2003). It is also interesting here to note the broad range of disciplines now taking Hip Hop as object for critical analysis: Education, English, Linguistics, and Sociology, amongst others. Michael Eric Dyson - one of the Hip Hop intelligentsia's more widely renowned voices - has concisely commented on the culture's widespread academic appeal, writing:

Hip-hop is being studied all over the globe, and the methodologies of its examination are rightfully all over the map. They are multidisciplinary in edifying, exemplary fashion, borrowing from sociology, politics, religion, economics, urban studies, journalism, communications theory, American studies, transatlantic studies, black studies, history, musicology, comparative literature, English, linguistics, and many more disciplines besides" (Dyson xiv).

Extending Dyson's claims, Murray Foreman avows: "today, having gained a certain respectability and reputation for analytic rigor - having paid its dues and earned its keep scholarly work on hip-hop is considerably less marginalized within the university" (3); still, while Hip Hop has been, for the most part, legitimized within academia as a cultural phenomenon worthy of scholarly attention, I am unaware of a Hip-Hop themed project being completed as a part of one's graduate work. Certainly, academic and critical research and considerations concerning one's own Hip Hop-based musical production is a novel venture. My project, as a fusion of theory with practice, has been to occupy this gap. My work may therefore be viewed as having ties not only to cultural and popular music studies, but also to that work done in more traditional genres within graduate-level music composition programmes. My specific concern is with how (independent Hip Hop) recording artists work to construct their own selves and identity (as formed primarily through lyrical content); simply put, my aim is to 
explore Hip Hop music and the construction of artistic self-presentation. I thus went about the task of creating my own album - my own Hip Hop-themed musical product - in order to place myself in the unique position to examine it critically as cultural artifact, as well as to write commentary concerning what it is I had hoped to accomplish or convey by my performance, whether or not (now looking back) I feel I was successful and, if not, where and how I may have faltered. In essence, my creative work acts as a case study from which discussion concerning theories of self-identity and self-presentation may be explored; my aim is to occupy a liminal zone in which Hip Hop practice and Hip Hop research may converge.

I seek to investigate cultural theory in practice and conceptions of personal identity linked to the political everyday; theoretical concerns are here to inform creative ones, with the creative conversely to ground the abstract. I am dealing with the issue of how I have sought to create an authentic, underground Hip Hop product. Accordingly, there is (at the most pointed level) the opportunity to explore what these terms - "authentic" and "underground" - actually entail and mean. I am here also dealing with issues tied to conceptions of identity generally: race, class, gender, and sexual orientation. Decisions made during the creative process are therefore of the utmost importance: Why did I choose to express myself in a particular way? Looking back, what decisions were made on an unconscious level? Even more interesting may be the question of why I, being educated and of the white working- to middle-class, have chosen Hip Hop music as a means for artistic self-expression. As a result, my project may be viewed as entailing many varied yet overlapping learning objectives, all focused around the fusing of theory with practice and the exploration of theories of identity presentation and the self.

I have chosen to address three main authors whose works I have found to be of especial influence and relevance, and whose studies represent critical tools through which my own work 
may be explored: Erving Goffman, Adam Krims, and Tricia Rose. Goffman's work, and particularly his The Presentation of Self in Everyday Life, will be employed as a classic text from which broader issues of self-identity construction may be discussed. As an overview, Goffman looks at the ways in which individuals present themselves and their activities to others, the manners in which people guide and control the impressions that are formed of them, and the kinds of things that people may or may not do while performing their various societal roles (Goffman xi). Particular attention will be paid to the "Performances" chapter of Goffman's "The Presentation of Self" as it is from this section that connections between self-identity and the performance of Hip Hop music (whether live or recorded, but for my purposes, focusing on the recorded) may most fruitfully be made.

Adam Krims, and specifically his Rap Music and The Poetics of Identity, will be used so as to focus my discussion on Hip Hop music in particular (and, even more pointedly, on the deconstruction of Hip Hop lyrics). Krims' work details rap's musical construction and how it, in turn, contributes to the formation of cultural identity - both for its audience and for artists. Of specific relevance will be his chapter entitled "The Musical Poetics of a 'Revolutionary" Identity"; in it, Krims looks at how Hip Hop signification operates by examining a specific text in order to "theorize some ways in which it may project (and help form) notions of a certain community and an identity" (Krims 93). Krims' work may consequently be taken as a pointed foundation on which I may base my own self-analyses.

Finally, Tricia Rose and her seminal Black Noise: Rap Music and Black Culture in Contemporary America, will be considered; certainly, this is a volume that has (arguably) done the most to popularize and legitimize academic study of Hip Hop culture. Rose's project, seeking to address critiques of Hip-Hop as racist, sexist, and homophobic, may be employed as a 
starting point from which to begin exploration of my own aforementioned position of privilege, as well as those negative elements often attributed to Hip Hop culture. Her chapter, entitled "Prophets of Rage: Rap Music and the Politics of Black Cultural Expression," should prove most valuable as it works to demonstrate the struggle between rap artists' (and their music's) often counter-dominant lyrical messages and the exercise of institutional power against them. Rose's theses may thus be taken as especially enlightening as I work to discuss, analyze, and deconstruct my own musical performance, coming as it is from a position of privilege (and especially from a position of whiteness) and actually composed within an institutional setting. Also, as a quick counterpoint and supplement to Rose's (rightful) black-focus - and in efforts to further explore my own racial identity - Bakari Kitwana's Why White Kids Love Hip-Hop will be briefly discussed.

In short, my paper will first discuss the general scholarly and technical processes encountered in completion of the the project itself (including relation of the project to course work and describing the practical methods to the project's completion ), as well as Hip Hop's cultural history and the norms of Hip Hop musical production. Such background is vital (especially for those unfamiliar with the culture) in laying the groundwork for understanding and framing of later theory, commentary, and (self-)analyses. Upon completion of preliminary materials, the above outlined tripartite theoretical discussion will then be engaged so as to form a conceptual framework through which commentaries may be understood and analyses made. Indeed, the commentary section, much of which is drawn from a reflective and analytic journal (kept by myself as an aid during my project's writing and recording processes), will then follow, At last, further (self-)analyses will then be made so as to extend links between practice and theory, theory and practice; my (self-)analyses section aims to extend those issues not fully 
explored through the aforementioned combination of theory and commentary. To be certain, all work is here completed with an eye to how self-identity is presented and formed (primarily through lyrical content), particularly in relation to my own recorded Hip Hop-themed musical product. It is hoped that the ensuing outlined theoretical framework and discussion will serve as a model through which other rappers/academics may think about, discuss, and analyze their own musical output, their own identities, their own selves. 


\section{PROJECT DESCRIPTION AND PROCESSES}

Critics of hip-hop ... make a point, of course - and it's not a point that's hard to make - that hip-hop is full of problematic expressions. ... . But this argument demands little engagement with hip-hop; these views don't require much beyond attending to surface symptoms of a culture that offers far more depth and color when it's taken seriously and criticized in proper fashion. It is odd that gifted intellectuals should so resolutely stick to superfluous observation, as if afraid of the intellectual credibility or complex truths they might find in a comprehensive study of hip-hop. It would be outlandish to comment on, say, metaphysical poetry without interacting critically with its most inspired poets. At least read Donne.

- Michael Eric Dyson, in his "Foreword" to

That's the Jointl The Hip-Hop Studies Reader, edited by Murray Forman and Mark Anthony Neal

The project at hand grew from a number of pointed factors and influences related to my general post-graduate research interests. Throughout my programme's course of study I have concentrated on relating both theory and practice to the exploration of youth cultures and popular music in general, and to the investigation of Hip Hop culture in particular. Focusing on Canadian Hip Hop culture, I produced a traditional thesis proposal as part of the programme's mandatory Research Methods Workshop (taught by Wendy Cukier). My aim was to compare Canadian Hip Hop products to their American counterparts in order to fashion larger claims concerning Canadian national identity and American cultural imperialism. As pointed to earlier, my initial proposal's literature review worked to position Hip Hop culture as a global phenomenon. Identifying a void in the writing concerning the study of Canadian Hip Hop culture specifically and, in a broader sense, Canadian popular music as a whole, my thesis proposal's research question was therefore termed thusly: Does Canadian Hip-Hop music have unique characteristics that distinguish it from the dominant American form? I proposed to answer this question primarily through quantitative content analysis, but also through both discourse and visual qualitative analyses. 
Even within a policy setting my focus remained on Hip Hop, especially in relation to larger cultural concerns. In "Issues in Communication and Cultural Policy" (taught by Professor Joy Cohnstaedt), I produced both a discussion and framework paper concentrating on Canadian Cultural Policy and Hip Hop culture. After positing Hip Hop and its encompassing arts-based activities as both valuable artistic and political tools, 'I worked to question whether current national policies were (or are) keeping pace with (the current Hip Hop) reality. Simply put, my discussion paper's research questions were termed as follows: Are current national policies impeding or enhancing the self-expression (particularly through Hip Hop) of Canada's youth? Should greater federal funding be granted to initiatives encouraging Canadian Hip Hop culture? Background for my inquiries was again global in scope - and I moreover dealt with specific discussion concerning popular culture and Canadian cultural identity. As a result of such background and discussion, it was suggested that through greater initiatives aimed at supporting and encouraging Canada's positive (or true) Hip Hop culture, policy-makers at the federal level may therefore work to support the broadening, export, and sovereignty of Canadian popular cultural identity and (most importantly) successfully evade institutionally discriminating practices.

As a result of such methodological- and policy-based work on Hip Hop culture, and having been recorded as a rapper in the past, I self-produced a Hip Hop track as part of my work in the programme's "Advanced Communication Technologies" course (taught by Michael Murphy). Such production allowed for a more fuller and well-rounded understanding of those objects which I had sought to analyze, deconstruct, and comment upon. In turn, more specific

1 Further description of what I see as constituting positive or "true" Hip-Hop culture is detailed in my following section, "Hip-Hop's Cultural History." 
theoretical work on Hip Hop music then came under the tutelage of Dr. Rob Bowman as part of his "Popular Music Studies" course. Professor Bowman's class allowed for my presentation of research related to genre theory and Hip Hop Jazz, as well as for the creation of a final term paper linking the African-American spiritual tradition through to other such "black" musical traditions as Gospel, Jazz, and the Blues (for which a link has already been made by a great number of other authors), and finally, to Hip Hop music (for which a link has not often been fashioned at any great length).

And so, in efforts to further fuse theory and practice, and in order to explore artistic selfidentity, the "cashtro hop project" was born. While I have wholly conceived and overseen completion of the project at hand, it did involve collaborative elements: I worked with In-Tune Audio - a recording studio located in Stratford, Ontario - primarily for recording and mastering purposes, but also for fashioning appropriate background instrumentals. As well, I worked with other producers whose services and instrumentals were acquired via the internet, and with other artists from Toronto and area, both for instrumental purposes and for vocal work (more on collaborators will be detailed below). Once a given instrumental was completed and chosen for inclusion, songwriting took place. It was then a matter of recording and mastering the recorded material, all of which took place in Stratford at In-Tune Audio. Indeed, while the final product is a Hip Hop-themed album of my own original (lyrical) content, it was only through In-Tune's constant mentoring that a project of this scale could be completed by a new artist with admittedly limited technical experience. As will be discussed, such collaborative efforts are certainly in line with Hip Hop's traditions of musical production. The creative work itself, loosely-defined, is a concept album, with tracks held together thematically by narrative sketches (or interludes) placed within the songs themselves - that seek to trace my (character's) disillusionment with Hip 
Hop culture, a subsequent enlightenment, and finally my use of positive Hip Hop as a means to self-expression and presentation. Pragmatically, the album is approximately one-hour in length, consisting of seventeen musical tracks. Also, an accompanying website has been designed and fashioned in order to disseminate and promote primary materials, while art for the album's cover has been commissioned and completed in consultation with Catherine Cachia, a local visual artist. 


\section{HIP HOP'S CULTURAL HISTORY}

"Rap" is as old as the African beating on a log like the one in which sailors keep their records, as old as the dictum that denied slaves drums because they were "rapping" to each other after hours, drumming up rhythmic resistance. When the rappers say "word," it is old.

- Amiri Baraka, in "The Language of Defiance"

Hip Hop is the only genre of music that allows us to talk about almost anything. Musically it allows us to sample and play and create poetry to the beat of music. It's highly controversial, but that's the way the game is.

- Grandmaster Flash, in his "Foreword" to The Vibe History of Hip Hop. edited by Alan Light

Hip Hop, as both a music and culture, is most often said to have begun in New York City - and specifically, The Bronx - in the early 1970s. Still, also of significance is Hip Hop's (and specifically rap's) deep roots in ancient African cultures and oral traditions. As Geneva Smitherman has avowed, the black community - from the time of slavery until now - has placed the highest of value on expression through spoken word (Smitherman 1977). Smitherman writes that during pre-slavery times, the concept of Nommo - word as life force-was widely ascribed to in African cultures. Simply put, conceptions of Nommo hold that "the Word" has "magical" powers that are necessary for the existence and ordering of life on earth (Smitherman 1977, 1997). For example, "in traditional African culture, a newborn child is a mere thing until his father gives and speaks his name" (Smitherman 1977: 78). Thus tying the oral tradition to modern rap, Smitherman muses:

Though often misunderstood (and even damned) for their nitty gritty language, especially the muthafucka's, ho's and niggaz, the Hip-Hop generation is coming straight outa the Oral Tradition. In that Tradition, language is double voiced, common English words are given unique Black meanings, and a muthafucka is never a person with an Oedipus complex (1994: 27). 
Of course, Hip Hop (and, specifically, rap music) has readily been damned as misogynistic, violent, and even homophobic - Smitherman herself concedes such; however, her further contention is that "Hip-hop/rap culture is a resistance culture. Thus, rap music is not only a Black expressive cultural phenomenon; it is, at the same time, a resisting discourse, a set of communicative practices that constitute a text of resistance against White America's racism and its Euro-centric cultural dominance" (Smitherman 1997: 7). Hip Hop culture can (or at least is) therefore often first stamped as part of black (American) culture; John F. Swzed writes, after tracing rap's roots into a variety of American cultural traditions, that "having noted rap's broad affinities, its American-ness, its creole emergence, and its lack of exclusive rights to be offensive, no one would be fooled into missing the fact that it finally is also very much an African-American form" (7). Still, while both Smitherman and Szwed are undoubtedly correct in linking Hip Hop to its African or black roots (and to its African-American roots), the participation of those of other ethnicities (including during the culture's most formative years) can not be ignored. Discussing the significance of the record "Rapper's Delight," Alan Light writes: "The revolutionary new sound and style that was being developed by black and Latino kids in the 1970s in the parks, clubs, and parties around New York City had been captured on wax, commodified with visible commercial results" (n. pag.). In turn, while not his main focus, Light's comments may thus function to acknowledge the role of Latino youth in the most formative years of Hip Hop's existence.

Indeed, this is a culture built on parties, with the man known widely as Hip-Hop's founding father, Kool Herc (born Clive Campbell), having made his DJ debut "in 1973 at his sister's birthday party, held in the recreation room of their housing project ... in the West Bronx" (Fernando 14). It was Herc who pioneered the breakbeat - cutting back and fourth 
between two records in order to extend the "break" or instrumental part of a song; this was the starting point not just for Hip-Hop music, but dance, techno, and jungle musics as well (Shapiro; Brewster). Dancing - or the art of b-boying - then grew from those dancers who saved their best moves for a song's break segment, and modern rapping grew from such early MCs as Lovebug Starski and Busy Bee reciting rhymes over Herc's (and other later such deejays') breakbeats.

This is also a culture that, at its essence, was both political and unifying. Afrika Bambaataa (born Kevin Donovan) - another of Hip Hop's most legendary pioneers - was first the leader of one of the South Bronx's most notorious street-gangs, the Black Spades. He also attended Herc's parties while working to form "the Organization": an association founded to unite several local projects against the threat of drugs and violence. As S.H. Fernando Jr. writes:

This initial community activism proved to be the blueprint for Bam's Zulu Nation, today known as the Universal Zulu Nation, an international hip hop movement that upholds such principles as knowledge, wisdom, understanding, freedom, justice, equality, peace, unity, love, and respect in their manifesto. Back in the day, though, the Zulus, who provided security at Bam's parties, were all about breakdancing, writing, graffiti, and furthering the emerging culture of the streets known as hip hop (Fernando 15). ${ }^{2}$

Besides Herc and Bam, it is widely held that Grandmaster Flash (born Joseph Saddler) be regarded as the third member of Hip Hop's holy (pioneering) trinity. Flash pushed the art of Djing forward with his penchant for technological innovation; also, he furthered the cause of Hip Hop culture as a whole by employing a group of five MCs, known collectively as Grandmaster Flash's Furious Five. The Five boasted more complicated routines than their predecessors, thus eventually helping the figure of the MC surpass that of the DJ in popularity. Surely, today, emceeing is the most prevalent and prominent of Hip Hop's elements, at least within a popular cultural climate. Attesting to

2 For more on the Zulus, see <http://www.zulunation.com/s. 
the Five's influence, their 1982 (signature) release, "The Message," achieved platinum

status in less than a month. The song is overtly political, pointing to the stresses of urban life ("The bill collectors they ring my phone / And scare my wife when I'm not home / Got a bum education, double-digit inflation / Can't take the train to the job, there's a strike at the station") - and, more specifically, ghetto urban life.

But it was with the release of the Sugarhill Gang's "Rapper's Delight" in 1979 that the world was first introduced to rap on a mass scale. ${ }^{4}$ And since the Gang's now controversial ${ }^{5}$ single was initially heard on airwaves, there has always been a commercial or mainstream versus underground or authentic divide within Hip Hop culture. To be sure, most Hip Hop enthusiasts would mark a recording such as "Rapper's Delight" - a party record void of any real political edge - as a mainstream or commercial product. By contrast, "The Message" - though also commercially successful - would often be hailed as

3 With respects to the group's concern with "ghetto" politics, witness the song's fifth and final verse: " $A$ child is born, with no state of mind / Blind to the ways of mankind / God is smiling on you but he's frowning too / Because only God knows what you go through / You'll grow in the ghetto, living second rate / And your eyes will sing a song of deep hate / The places you play and where you stay / Looks like one great big alley way / You'll admire all the number book takers / Thugs, pimps, and pushers and the big money makers / Driving big cars, spending twenties and tens / And you wanna grow up to be just like them / Smugglers, scramblesr, burglars, gamblers / Pickpockets, peddlers, even pan-handlers / You say I'm cool, I'm no fool / But then you wind up dropping out of high school / Now you're unemployed, all null and void / Walking around like you're pretty boy floyd / Turned stickup kid, but look what you done did / Got sent up for a eight year bid / Now your man is took and you're a may-tag / Spend the next two years as an undercover fag / Being used and abused, and served like hell / 'Til one day you was found hung dead in a cell / It was plain to see that your life was lost / You was cold and your body swung back and forth / But now your eyes sing the sad sad song / Of how you lived so fast and died so young."

4 "Rapper's Delight," recorded by the Sugarhill Gang for Sugarhill Records, is commonly held as the greater public's first introduction to Hip-Hop (as commercial commodity), though it should be noted that a lesser-known rap song by Brooklyn's Fatback Band - entitled "King Tim III (Personality Jock)" - had actually come out on Spring Records several months prior.

5 Controversy surrounding the single comes from a variety of sources. The three members of Sugar Hill are thought to have not been fully immersed in the growing Hip-Hop culture, but instead merely picked by Sugar Hill Records' head, Sylvia Robinson, to record the song. Also, most of the rhymes used on the record are said to have come from other rappers; the Hill's Big Bank Hank, for instance, was reciting the rhymes of Grandmaster Caz. For more on the Sugar Hill controversy, see Jim Fricke and Charlie Ahearn's Yes Yes Y'All: The Experience Music Project: Oral History of Hip-Hop's FirstDecade, and specifically their chapter entitled "Rapper's Delight: Hip-Hop Goes Commercial." 
an underground or authentic product. Mainstream or commercial recordings may readily be characterized as (aside from having any real political edge): regularly employing extended and easily recognizable samples from already popular songs; frequently using imagery tied to guns, violence, material wealth, and sexual prowess (in the manner of past "gangster" rap recordings - but without any real political context) ${ }^{6}$; and ones that utilize popular rhythm and blues singers of the day for the purposes of reciting a given song's chorus (or hook). This is not to aver that a record held by the majority (of those within the culture) as true or authentic could not contain such elements; rather, it is to suggest that there is certainly a bulk of products held as mainstream and commercial that contain such features.

For my paper's purposes, true (and positive) Hip Hop culture and its manifestations may be taken as in accordance with the the Temple of Hiphop's "Hiphop Declaration of Peace" (see Appendix 1) presented to UNESCO delegates on the 16 May 2002 in New York City. Founded by another of Hip Hop's pioneers, KRS-One, the Temple espouses Hip Hop culture as "an alternative behavior capable of raising one's self-awareness, selfworth, and self-respect." "7 This is what I would deem real or authentic, particularly in opposition to the characteristics of mainstream or commercial recordings (as outlined above). The Temple of Hiphop supports only elements of the culture that function to promote an empowering lifestyle or, - as cliché as it may be - peace, love, unity, and having fun.

6 More on the gangster genre of rap music will follow, especially in my section on Adam Krims' work.

7 See $<$ http://www.templeofhiphop.org $>$ for more on the Temple. 


\section{NORMS OF HIP HOP CULTURE AND ITS TRADITIONS OF MUSICAL PRODUCTION}

Many critics ... don't account for the complex ways that some hip-hop artists play with stereotypes to either subvert or reverse them. For instance, amidst all the pimp mythologies and metaphors that weigh heavily on branches of contemporary hip-hop, rappers like Common seize on pimpology's prominence to poke fun at its pervasiveness. But its critics often fail to acknowledge that hip-hop is neither sociological commentary nor political criticism, though it may certainly function in these modes through its artists' lyrics. Hip-hop is still fundamentally an art form that traffics in hyperbole, parody, kitsch, dramatic license, double entendres, signification, and other literary and artistic conventions to get its points across.

- Michael Eric Dyson, in his "Foreword" to

That's the Joint! The Hip-Hop Studies Reader, edited by Murray Forman and Mark Anthony Neal

Certainly, the African emphasis on the power of the Word goes hand-in-hand with how "verbal battles" have historically accompanied African warfare. From the African epic of Sundhita to the standoff between two street-gangs, word-barbs have often accompanied physical conflicts (Smitherman 1977). In the present, verbal battles have become a war unto themselves. The modern concept of the "freestyle" or "battle rap" - in which two participants take turns rapping and trying to outwit one another - may here serve as evidence. Moreover, the tradition of the battle rap may additionally be connected to the black linguistic traditions of the dozens (or playin the dozens) and signification (or signifyin); indeed, as Geneva Smitherman writes: "rap music is rooted in the Black oral tradition of tonal semantics, narrativizing, signification / signifyin, the dozens / playin the dozens, Africanized syntax, and other communicative practices" (1997: 4). To be sure, the dozens involves one employing "verbal insult[s], the most common being 'yo momma"' (Smitherman 1997: 13) aimed at another's relatives, while "signification/signifyin is a type of verbal insult that is leveled at a person, rather than at his or her mother or relatives" (Smitherman 1997: 14). Much of rap is of the battle variety, whether 
aimed at a real or imagined opponent. This is the art of the boast, the art of the toast; John F. Szwed writes:

The most likely candidate for a direct forebear of modern rap is the toast, the rhymed monologue, an African-American poetic form that typically recounts the adventures of a group of heroes who often position themselves against society either as so shrewd and powerful as to be superhuman, or so bad and nasty as to be subhuman. Toasts tell stories ... that could thrive in the prisons, the army, and on the street (8).

An even more direct antecedent of rap music may be the practices of those radio DJs who, extending the toasting tradition, made rhyming commentary a part of their routine as they spoke between and over records. Soon, such a practice became popular in Jamaica, and such artists as "Yellowman and Big Youth were chanting long stories in rhyme form, for which they were labeled toasters" (Szwed 9).

Besides boasting or toasting, another of Hip Hop music's most discussed conventions is the practice of sampling. Sampling may be defined as taking a segment of an existing recording and placing it into a new song; often, a musical sample will be looped or repeated so as to make up a rap track's instrumental backing. Concerning the rise of sampling practices, Murray Forman writes: "By the mid-1980s, digital sound sampling had become a standard technological component of music production, again modifying the standards and skills involved in rap production. Sampling was rapidly integrated into rap's studio arsenal, introducing radical capabilities that transformed the way music was conceived and constructed" (390). Of course, while rap's sampling practices are derided by some as uncreative or, worse yet, a case of creative property theft (with the accompanying copyright law implications), Geneva Smitherman's contention is that Hip-Hop, through such practices as sampling, "revisit[s] earlier musical work" (1977: 15); she avows: "As a rhetorical strategy, sampling is a kind of structural signifyin ... The sampling of rappers thus represents a conscious preoccupation with artistic continuity and 
connection to Black cultural roots. In this sense, the Hip Hop Nation is grounding itself squarely and unabashedly in the Black musical-cultural tradition, even as they extend that tradition" (Smitherman 1997: 15-16).

Hip Hop music also widely employs the convention of the skit or interlude. A skit is akin to an audio sketch or scene, and is often used for comedy purposes and/or to further the concept of a given album. The first Hip Hop skit was produced by Prince Paul and appeared as the opening to the group De La Soul's 1989 album, Three Feet High and Rising. The practice of including skits on Hip Hop albums has since become a common staple and, even, a kind of tradition. To be sure, a decade after his pioneering work with De La, Prince Paul employed a slew of skits in order to further the narrative of his tightly devised 1999 concept album, $A$ Prince Among Thieves.

Finally, besides the conventions of boasting or toasting, the practice of sampling, and the widespread use of skits within Hip Hop music, it should be noted - especially for the purposes of my study - that rap is very much a linguistic form. Of course, Smitherman's work regularly points to this, but my crystallizing of this thought is done in the vein of Michael Eric Dyson's quotation that serves as the epigraph to this section. As such, Hip Hop music also often employs those conventions commonly found within literary creations: hyperbole, parody, satire, dramatic license, and the like. Surely, this is important to keep in mind when exploring presentation of the self, particularly as it relates to lyrical analysis. 


\section{THEORETICAL FRAMEWORK I}

\section{PRESENTATION AND THE SELF:}

\section{ON THE WORK OF ERVING GOFFMAN}

When an individual plays a part he implicitly requests his observers to take seriously the impression that is fostered before them. They are asked to believe that the character they see actually possesses the attributes he appears to possess, that the task he performs will have the consequences that are implicitly claimed for it, and that, in general, matters are what they appear to be.

- Erving Goffman, The Presentation of Self in Everyday Life

Erving Goffman, in the preface to his The Presentation of Self in Everyday Life, explicitly asserts that his study works to propose a model representing one sociological perspective from which social life may be analyzed:

The perspective employed in this report is that of the theatrical performance; the principles derived are dramaturgical ones. I shall consider the way in which the individual in ordinary work situations presents himself and his activity to others, the ways in which he guides and controls the impression they form of him, and the kinds of things he may or may not do while sustaining his performance before them (Goffman xi).

Certainly, while the presentation of Hip Hop and its varying elements would not usually be categorized as "ordinary," my suggestion here is that the pervasiveness of Hip Hop as culture works to challenge notions of what is to be deemed commonplace. Indeed, Goffman does regularly reference musical performance in the body of his work, and so his theoretical model may readily be deemed applicable to various studies of rap. The preface goes on to contend that "the stage presents things that are make-believe; presumably, life presents things that are real and sometimes not well rehearsed" (xi); surely, study of Hip Hop as performance here clearly complicates "The Presentation of Self": while much of Hip Hop culture does entail that which may be marked as part "stage," the efficacy of the now-cliched mantra that is "keeping it real" can not be discounted. As will be discussed in the section on Adam Krims (below), Hip Hop 
music is often deemed authentic only when thought to accurately portray the artist's real-life; and so, here is one glaring example of an instance where art and identity collide. Also of note, much of Hip Hop music is regularly deemed "not well rehearsed" - and lauded as such. Goffman concludes his preface by writing that his framework draws on, as he asserts, various "bits of experience" drawn from both respected research projects and "informal memoirs written by colourful people" (xi); my work, at the very least, may thus be taken as adding another more contemporary bit of experience through which the presentation of self may be explored.

Beginning his specific treatment of performances, Goffman works to consider, as he writes: "the individual's own belief in the impression of reality that he attempts to engender in those among whom he finds himself" (17). At one extreme, performers may be so taken in by their own act that they believe their staging of reality to be the real reality. Then, at the other extreme, performers may not be taken in by their own presentation; this also is a possibility that "is understandable, since no one is in quite as good an observational position to see through the act as the person who puts it on" (Goffman 17). Certainly, taking Goffman, one can expect to experience concerning his or her own performance a cycle of belief-to-disbelief, disbelief-tobelief, or even a movement back and fourth between such feelings of sincerity and cynicism. Nevertheless, while such movement may be marked as natural, Goffman writes that "we must not rule out the kind of transitional point that can be sustained on the strength of a little selfillusion." (Goffman 21). The point here is that while performing individuals may work to have their audience react in a particular (and believing) manner, still the performers themselves may not wholly believe the impression of reality they are attempting to foster is credible. Given that one's personal belief in his or her actions (or, to put it more simply, one's "confidence" in his or 
her work) is surely paramount to the make-up of one's (self-)identity, Goffman's contentions will thus serve as a fitting starting point for my own self-analyses.

Related to belief and included as part of one's performance, Goffman writes of the "front" - or the "part of the individual's performance which regularly functions in a general and fixed fashion to define the situation for those who observe [it]" (22); to be sure, a front may be defined as involving "expressive equipment of a standard kind intentionally or unwittingly employed" (Goffman 22) by a given performer. For Goffman, one standard element of a given front is the setting or scenic aspects of the individual's performance; certainly, since my considerations are here primarily with self-identity vis-a-vis voice recording, this element is not worthily applicable. However, Goffman writes also of the "personal" front which, he asserts, refers "to the other items of expressive equipment, the items that we most intimately identify with the performer himself and that we naturally expect will follow the performer wherever he goes" (24). As part of the personal front, Goffman includes such characteristics as a given individual's office or rank, sex, age, and racial characteristics, size and looks, speech patterns, facial expressions, bodily gestures, and the like (24). Of course, much of the personal front is therefore also tied to the visual, but it should be noted that one's voice and articulative practices can surely convey (a performance of) various aspects of his or her office or rank, sex, age, race, size, looks, and bodily gestures; also obvious concerning the performance of rap and voice recording as a whole, attention to one's (the performer's) speech patterns is of the highest order.

Concerning aspects of a given social front and the relations between them, Goffman writes of what he terms "abstractness" and "generality." His contention is that "however specialized and unique a given routine is, its social front, with certain exceptions, will tend to claim facts that can be equally claimed and asserted of other, somewhat different routines" (26). 
Though this will further be elaborated upon in my analysis section, I will for now suggest that, concerning Hip Hop music specifically and even the recording of all musics in a broader sense, individuals often strive in their performances both for originality or uniqueness as well as similarity: originality in order to offer something new and differentiate creative products from others already in existence; similarity so as to appeal to audiences already in existence and be placed into a given (sub-)genre (however loosely-defined it may be). Indeed, in relating to a given performance, Goffman writes that observers are encouraged to stress abstract similarities: "Instead of having to maintain a different pattern of expectation and responsive treatment for each slightly different performer and performance, he [the observer] can place the situation in a broad category around which it is easy for him to mobilize his past experience and stereo-typical thinking" (Goffman 26). The contention is that observers of a given performance need only a limited, experiential vocabulary concerning various fronts - and know how fittingly to respond to them - in order to orient themselves in a relatively vast and varied number of social circumstances.

In attempting to relate the validity of a given performance, Goffman writes also of "dramatic realization" - or the manner in which individuals attempt to confirm that their performance (or "front") is to be especially significant to others. This is where "the individual typically infuses his activity with signs which dramatically highlight and portray confirmatory facts that might otherwise remain unapparent or obscure" (Goffman 30). Performing individuals attempt to have their performance validated in the minds of onlookers, thus presenting a pointed example of activity being transformed into show. Goffman writes that the performance of such roles as those held by prizefighters and violinists are ones in which dramatization presents little difficulty, since such activities allow for acts essential to the completion of the core task to often 
be "wonderfully adapted, from the point of view of communication, as means of vividly conveying the qualities and attributes claimed by the performer" (Goffman 31). Surely, performance of identities tied to musics (witness Goffman's referencing of the violinist) are to be marked as allowing (or, I would suggest, encouraging - and even demanding) dramatization. Still, what arises here is the dilemma of what Goffman terms "expression versus action" (Goffman 33). Citing Sartre, Goffman's suggestion is that individuals may so wish to express a given performance - for example, students performing attention to their teacher - that they may become exhausted in the playing of that role and thus unable to actually perform that role. A fitting illustration of this dilemma related to Hip- $\backslash$ Hop music would be the case of the "ghostwriter" who actually writes lyrics, and those "rappers" who (using ghostwriters, are often deemed inauthentic) then perform those lyrics. To be sure, greater exploration of dramatic realization and the "expression versus action" dilemma related to my own work will be elaborated on in my analysis section.

Especially related to the contention that performances, through their fronts, present abstract claims upon a given audience (that are also present within other performances), is the obvious realization that a given performance is "socialized"; still, Goffman writes that this points also to an important aspect of the socialization process: "the tendency of performers to offer their observers an impression that is idealized [emphasis mine]" (Goffman 35). Sure enough, music recording artists often seek to present an idealized version of themselves and their performance, especially as compared to their live work. Simply put, their recorded performance is to be a model example of musical skill as it relates to audience expectation; Goffman writes: "when the individual presents himself before others, his performance will tend to incorporate and exemplify the officially accredited values of the society" (35). Thus, a given performance works to 
highlight "the common official values of the society in which it occurs" (Goffman 35) and may function, then, "as a ceremony - as an expressive rejuvenation and reaffirmation of the moral values of the community" (Goffman 35); here then, a given performance that can be marked as "Hip Hop" may be viewed in context of the culture at large. Surely, just as Goffman writes that "upward mobility involves the presentation of proper performances" (Goffman 36), so too would more ideal musical performances be sought in effort to gain greater favour with one's audiences. In turn, Goffman writes also of concealment, so that, for instance, one that is to present a front as religiously pious will only engage in what would otherwise be deemed inappropriate behaviour when it is concealed; dealing with Hip Hop and my project specifically, prominent display of, for instance, my educational status (or that which may normally be concealed within other Hip Hop musical products) will be discussed within my analysis section.

Goffman also warns that just as audiences may interpret through minor cues that the performer's act is of importance, so too may they misinterpret a performer's intent or "read an embarrassing meaning into gestures or events that were accidental, inadvertent, or incidental and not meant by the performer to carry any meaning whatsoever" (Goffman 51). Accordingly, Goffman concerns himself with the maintenance of expressive control, or how performers often work to exert what he terms a synecdochic responsibility, making sure that as many of the performance's minor events occur in such a way so as to convey either no impression or an impression that is compatible with the performance being fostered (Goffman 51). Of course, accidental gestures and the like may occur in live music performance, but they are to be controlled and edited in the case of recorded musics; however, misreading of musical texts, particularly (concerning my own work) those pieces meant as parody or satire, should certainly be explored. 
And just as performers must be weary of misrepresenting themselves, so it follows that audiences must be weary of being fooled; for if audiences accept signs from performers who must figure their position as able to be misunderstood (and thus must exercise great care in the dissemination of their front), "so also this sign-accepting tendency puts the audience in a position to be duped and misled, for there are few signs that cannot be used to attest to the presence of something that is not really there. And it is plain that many performers have ample capacity and motive to misrepresent the facts" (Goffman 58). Dealing with self-analysis, my intentions must be taken as genuine, though surely the projected interpretation of my message should be analyzed and discussed. At the very least, if I am not sincere, I am, to appropriate Goffman, "sincerely convinced of [my] own sincerity" (71). Members of a given audience are naturally inclined to feel that the performance they are viewing is true or false, genuine or spurious; thus, discussions of authenticity (related to my own work) are to be explored. As Goffman writes: "Some times when we ask whether a fostered impression is true or false we really mean to ask whether or not the performer is authorized to give the performance in question, and are not primarily concerned with the actual performance" (Goffman 59). Questions here surrounding my racial, socio-economic, and educational identity may therefore be explored, especially in wake Krims' and (to an even greater extent) Rose's theoretical schema (to be discussed below). Employing Goffman, the question here is not "What are the ways in which the given impression [I mean to foster] is false?" but, rather, "What are the ways in which [the] given impression [I mean to foster] can be discredited?" (66). 


\section{THEORETICAL FRAMEWORK II}

\section{(GANGSTA) RAP MUSIC AND THE POETICS OF IDENTITY: THE WORK OF ADAM KRIMS}

This chapter is an attempt to examine a song and theorize some ways in which it may project (and help form) notions of a certain community and identity. . . . "Identity" does not necessarily mean "resistant identity"; thus, while the project here may resemble in some respects those for which m usic may be validated as radical practice or resistance to domination, the only operative assumption is that somehow the identities being discussed are formed symbolically - not necessarily that they overturn the discursive structures lined up against them.

- Adam Krims, Rap Music and the Poetics of Identity

Adam Krims, in the introduction to his RapMusic and The Poetics of Identity, expressly avows that his project is to "advance an argument that the sonic organization of rap music - both the rapping itself and the musical tracks that accompany it - is directly and profoundly implicated in rap's cultural workings (resistant or otherwise), especially in the formation of identities" (2). In particular, he seeks (fittingly for my project) to deal with recorded rap musics, his contention being that "such is the form in which a great many people know it and make it a part of their lives" (Krims 1). To be sure, Krims sees a focus on rap as a source of identity as very much in line with the more recent concerns of popular music studies as a whole (Krims 9). Of course, my project here is to deal with identity related to the artist and, more pointedly, the self. Still, this is not to discount the formation of identities related to rap audiences (or Hip Hop audiences in a more general sense), nor to lose sight of rap music (and music in a more general sense) as a locale for collective identity formation; rather, it is simply to give my work more focused aims and a tighter scope.

Krims pays especial attention to the formation of artistic (self-)presentation in his chapter entitled "The Musical Poetics of a 'Revolutionary' Identity." He is here working to describe the 
operation of signification as it relates to a particular track: Ice Cube's "The Nigga Ya Love to Hate" (see Appendix 2 for a transcript of lyrics). Krims' general discussion shall thus function as a tool through which my own work will be explored; moreover, his pointed analysis of the song in question should serve as a fitting example by which my own work may be deconstructed. Krims begins his chapter by focusing on those notions of culture put forward by James Clifford in The Predicament of Culture. Krims asserts that Clifford sees as a condition of the (post-) modern the sense that some notion or essence of authenticity has been mislaid and lost. And though this sense is often presented as mere nostalgia for some earlier notion of that which is "pure," Krims writes that Clifford himself does not see society as inhabited by endangered authenticities; "rather, the situation, as he sees it, prompts the question, 'What are the essential elements and boundaries of a culture?" (Krims 94). Accordingly, cultural identity is not to be viewed as tied to some imagined and pure past; rather, it is to be tied to "matter[s] of continual appropriation, revision, and creation in the present, with an eye toward the future" (Krims 94). While one of my paper's paramount aims is to analyze how my own creative work may operate as part of Hip Hop culture, the more crucial consideration may be - dealing as I am with selfpresentation - those decisions made during the writing and recording process where I overtly worked with the aim of having my work positioned as part of the culture.

Krims, appropriating Clifford, thus writes that cultural identity, "brings to the fore a 'need to stage authenticity in opposition to external, often dominating alternatives' ... In the process, 'The roots of tradition are cut and retied, collective symbols appropriated from external influences"' (Krims 94). In consequence, authenticity in art may be marked as relational. Further appropriating Clifford, Krims asserts: "there can be no essence except as a political, cultural invention, a local tactic" (Krims 94); this, I would suggest, is a hallmark of the post- 
modern. Surely, as has been touched upon and will be further fleshed out, my project's aim was not just to create a product that could be marked as "Hip Hop," but also a product in opposition to much of mainstream rap. Questions of authenticity are here in turn complex, operating on the most contested of grounds. Rose's study, working as she does to elaborate on rap as a means to critiquing dominant social power structures, will further complicate.

Especially concerning the "gangsta" genre of rap, Krims considers the issue of artistic persona. As has been well-documented, a principal authenticating strategy of gangsta rap has been "the symbolic collapsing of the MC onto the artist [and] the projection that the MC himself (with the gender-specific pronoun purposefully unmodified) is the persona - a voice from the 'streets,' speaking from authentic experience" (Krims 95). This is the act of "keeping it real," or - to play on Goffman - of not presenting a mere "front." Certainly, my own creative work stands in opposition to gangsta rap both in an implicit and explicit sense: implicitly because I am (as has already been recognized) not a terribly legitimate voice "from the streets"; explicitly because through my creative work I have sought (as has already been commented upon) to criticize the gangsta persona and its accompanying lyrical imagery. ${ }^{8}$ Concerning Ice Cube specifically, Krims writes that his entire early persona depended on the collapsing of the aggressive and politically-charged MC "front" (to again borrow from Goffman) onto the historical and "real-life" figure of O'Shea Jackson (Cube's given name); correspondingly, "while the identity formed in the song 'The Nigga Ya Love to Hate' is as virtual, in a sense, as that of any singing or rapping voice in a song, the production of that identity serves a dual purpose.

8 Still, I feel compelled here to note that I am personally less - if at all - critical of Ice Cube and the like ("gangsta") rappers' position (which I would mark as political and authentic) as I am of the more recent and commercially-marketed gangsta rappers who I see as very much a caricature of what Ice Cube and NWA once were; I mean to suggest that current gangsta acts (say, for example, 50 Cent) seem to display the trappings and outward material signs of the gangsta life but with music that lacks a more outward political or didactic edge. 
'The Nigga Ya Love to Hate' here is both persona and artist, the formation of the necessary collapse of the two which one may see as synonymous with 'keeping it real'" (Krims 95). Again, questions of my own authenticity, my own persona, my own attempts at "keeping it real," are therefore to be discussed.

Krims is especially useful and unique in working to detail how, through the track in question, Ice Cube defines a specific "political stance within his [black] community, not only against the hegemonic culture, but also against fellow blacks that he sees as helping to perpetuate the culture's injustices" (Krims 96). Here is the notion that Cube's work fashions a kind of "black revolutionary identity" (to appropriate Krims' own terming). Precising analysis of the text at hand, Krims writes:

The song stages, among other things, Ice Cube's role in political and cultural resistance to the dominant white culture.... Verses in which Ice Cube raps alternate with refrains, in which Ice Cube confronts verbal attacks and responds to them. The first two verses ... elaborate what Ice Cube regards as politically motivated attempts to silence him, and his success at communicating despite them. The final verse ... criticizes other blacks in the entertainment industry for reinforcing existing power structures. At the end of the final verse, Ice Cube instructs listeners to emulate him, despite (and because of) his failure to conform to traditional images of "role models" that he obviously rejects (Krims 102).

Paying specific attention to the track's semantic operation, Krims notes Ice Cube's description of other black performers (in the song's third and final verse) as a fitting locale to begin observing the operation of Cube's black revolutionary identity. Ice Cube identifies Soul Train (the once-popular black-oriented music television show) as having lost its soul, saying that it looks, instead, "like a Bandstand" (referencing American Bandstand, another music show that was designed primarily for white audiences). Arsenio Hall is also negatively referenced, "though a reason is not given" (Krims 103). Cube also notably rejects those entertainers who dance, prompting Krims to comment: "In fact, in much of Ice Cube's music, and in some of his 
interviews, he has made it clear that his music is only secondarily for entertainment; he thinks of his role as primarily that of an educator about life in the ghetto" (103). Thus, the use of rap music solely for entertainment purposes (or for dancing) is, for Ice Cube, a betrayal of its potential and power. In short, building on Krims, I would suggest that Cube sees his music, first and foremost, as serving a didactic purpose; indeed, early in the track, he raps: "I never / tell you to get down, it's all about comin' up." He is against the "suckas that went pop," or those that would use Hip-Hop music solely for entertainment. To be sure, Krims writes that "The Nigga Ya Love to Hate" contains a myriad of references to Cube's self-identified role as educator.' "Rap Music" is further unique in its discussion of rap's "layering" and other more musical elements. Though my main concerns here are with Hip Hop music's linguistic aspects (as they relate to identity formation), still Krims is useful in providing a vocabulary for more purely musical analysis. Indeed, as these elements often inextricably relate to and ground a given rap song linguistically (and can be used so as to analyze my own work), some points should therefore be brought to the fore. Krims notes that "The Nigga Ya Love to Hate" contains an initial musical density than can be said to coincide with Ice Cube's more overt bravado in the song's first two verses; it is here that Cube concerns himself with those that would have him silenced - and how he overcomes such forces (especially enforced semantically with the track's first two choruses). The process then climaxes with Cube's mentioning of Soul Train before

9 There are five specific lyrical excerpts from "The Nigga Ya Love to Hate" that I, partially appropriating Krims" thought, would identify as obvious cites where Ice Cube may be viewed as overtly didactic and working to frame himself as educator: (1) the lines, "And sayin' peep about gangs and drugs, you / Wanna sweep a nigga like me up under the / Rug, kickin' shit called Street Knowledge, / Why are more niggas in the pen than in college?"; (2) the line, "Da Mob is droppin' common sense"; (3) the lines, "Thinkin' not about how right and wrong ya live, but how / Long ya live, I ain't with the bullshit"; (4) the lines, "And tellin' young people what they gotta know, 'Cause I hate it when niggas gotta lay low"; and (5), the song's final six bars in which Ice Cube raps, "It ain't wise to chastise and preach, / Just open the eyes of each, 'cause / Laws are made to be broken up, what / Niggas need to do is start lookin' up, and / Build, mold, and fold themselves into/ Shape, of the nigga you love to hate!" 
quickly decreasing in density as Cube speaks of his disdain for Arsenio Hall (Krims 111). ${ }^{10}$ As well, "the final focus on percussion ... coincides with the final negative reference to black television entertainment (a more generalized image of blacks trying to 'outdance one another')" (Krims 111). As has been outlined, the dance aspect of black musics is framed negatively by Ice Cube, as are those who support such images; thus, Krims avows:

The isolation of a percussive dance beat is not a neutral illustration; rather, it is an ironic quotation. In this sense, the textural climax and the gradual isolation of percussion become an occasion for a two-sided projection of black musical identity. On the one hand, the musical elements gradually acquire rhythmic force and the percussion becomes prominent in the manner generally characteristic of break beats; this would normally be the occasion of an appreciation of the rhythmic drive that often helps propel rap music. But, on the other hand, this appreciation, and a common response - dance - are being stigmatized as contrary to the song's purpose. A pleasure is created at the same time as it is stigmatized.

Consequently, there emerges what Krims calls, appropriating Henry Louis Gates Jr., "motivated Signifyin"" where "an element of cultural production is quoted and troped for the purpose of critique" (Krims 112). Ice Cube's framing of popular images surrounding black people thus functions to create a kind of counter-(self-)identity. My project, especially considering the creative work's more satirical pieces, may be viewed, in this sense, in a parallel manner. By track's end, Cube's phrase "the nigga ya love to hate" has then been transformed from derogatory to positive; it has become, to appropriate Krims, Ice Cube's black revolutionary identity. Indeed, "it is significant that Ice Cube speaks of 'build[ing], mold[ing], and fold[ing]' oneself into shape; the conscious effort to create an identity is explicit, as is its ongoing and dynamic structure" (Krims 116). In the first verse, the phrase is a kind of object of fear and animosity; in the second, it is presented comically (especially as it concerns the "ol' ladies"); and,

10 Krims notes that when "The Nigga Ya Love to Hate" was first released, Arsenio Hall was "among the most visible black presences on television, particularly for hip-hop fans and rap music listeners" (Krims 111). 
in the final verse, the "nigga ya love to hate" has become, as Krims puts it, "something to emulate as a strategy of political resistance" (116).

The argument is not simply that Ice Cube can be used as a tool with which cultural critics can concern themselves with issues of identity, but that Cube himself is also explicitly concerned with his own presentation - he is concerned with his self-presentation - and not just as it relates to his persona, but as it relates to his lyrical referencing of those in power. His rapping, "Once again, it's / All in the muthafuckin' cycle: Ice / Cube the bitch killa, cop killa," points to the cultural image of Ice Cube, and rappers in general, as brutalizers and murderers of police and women; "thus, this exceptional moment in the song highlights in its own way the issue of representation" (Krims 117) - and Cube's recognition of such; his work operates, here, selfreflexively. Cube is cognizant of the media's (cyclical) portrayal of he and his peers in a narrow and specific manner. Again, Rose's work will elaborate on rappers as purveyors of counterdominant public speech, for she aims also to explore the exercise of dominant power structures against such artists. For now, it should be noted that my work can also be explored in terms of identity and reception by those with institutional power. 


\section{THEORETICAL FRAMEWORK III}

RAP AND RACE:

ON TRICIA ROSE AND BAKARI KITWANA

Public Enemy's prophet of rage, Chuck D, keeps poor folks alert and prevents them from being lulled into submission by placating and misleading media stories and official "truths." He holds the microphone with a vice grip and protects it from perpetrators of false truths, speaking directly to the poor, using indirection and symbolic reference. When Chuck D says that pouring it on in metaphor is nothing new, he refers to the long history of black cultural subversion and social critique in music and performance. In this sense, rap is "nothing we ain't done before." Slave dances, blues lyrics, Mardi Gras Parades, Jamaican patios, toasts, and signifying all carry the pleasure and ingenuity of disguised criticism of the powerful.

- Tricia Rose, Black Noise:Rap Music and Black Culture in Contemporary America

"When I was in high school," Matthew tells me, "a friend came up to me one day and told me that he had been writing rhymes for about a year, but was afraid to tell anyone. It was normal for that to happen back then. We still got made fun of by some of our friends for being white and into hip-hop. Looking back on my formative years, I see that we were trying to create an identity for ourselves that was more substantive than what we were handed in public school, church or any other outlet. We were really fighting for our spirits, fighting to define ourselves outside of mainstream American society by latching onto an oppositional identity and the perceived power in hip-hop."

- Bakari Kitwana, Why White Kidss Love Hip-Hop

Tricia Rose, in her now-seminal Black Noise, devotes a chapter of her work to pointedly exploring "Rap Music and the Politics of Black Cultural Expression." In this section, she opens her discussion by referencing the work of Chuck D - the front-man for Public Enemy who once famously referred to rap as the "black CNN" - who Rose affirms speaks to the (black) poor through an art-form steeped in the history of black cultural expression and subversion. Rose's contention is that, in a climate in which expressed disapproval of those in power is strategically unwise or often contained, the oppressed thus utilize language, dance, and music in order to critique and mock those in power, express rage, and produce dreams of subversion; "these dances, languages, and musics produce communal bases of knowledge about social conditions, 
communal interpretations of them and quite often serve as the cultural glue that fosters communal resistance" (Rose 99-100). On a meta-level then, Rose's discussion of Hip Hop is very much framed as a culture that is enacted by and for the poor, and particularly by and for those poor people of colour; indeed, her concern is with rap music and black cultural expression - and with a strict American focus. Being white and Canadian, Rose's work may be thought dismissible in relation to my self-analyses; still, hers is a tour-de-force within Hip Hop academia that must be considered, and may be used to shed light on questions of identity generally, and questions of my own identity - particularly as it relates to what I am not - in particular.

Referencing James Scott, Rose marks rap music as a "hidden transcript" - or that which "critiques and resists various aspects of social domination" (Rose 100). Rose writes of how rap often uses a kind of cloaked speech and disguised cultural codes in efforts to challenge and critique unequal power structures. And while not all of Hip Hop's musical "transcripts" may be characterized as political, it is her contention that, "nonetheless, a large and significant element in rap's discursive territory is engaged in symbolic and ideological warfare with institutions and groups that symbolically, ideologically, and materially oppress African Americans" (Rose 100-101). Rose affirms that rappers often function to "act out inversions of status hierarchies, tell alternative stories of contact with police and the education process, and draw portraits of contact with dominant groups in which the hidden transcript inverts/subverts the public, dominant transcript" (Rose 101). Still, in a contemporary society where popular culture is heavily mass-mediated, resistant transcripts - such as rap - are readily absorbed into the public domain and subject to incorporation and increased scrutiny. Such subjugation may certainly have a negative effect, though Rose further notes that, because of mass media and distribution, these 
"alternative codes and camouflaged meanings are also made vastly more accessible to oppressed and sympathetic groups around the world and contribute to developing cultural bridges among such groups" (Rose 101). Rap's resistive transcripts may therefore be characterized as presented in both public and hidden domains as widely disseminated and simultaneously difficult to confine cultural products. Hence, while Public Enemy may acknowledge that they operate in a long-line of black cultural expression and subversion, Rose writes that what makes the group unique is their ability to occupy a popular cultural stage while also functioning as a means of social criticism.

Of course, rap has (often rightfully) been criticized as sexist, misogynistic, and even homophobic; Rose herself writes of the ways in which aspects of Hip Hop music support and affirm varying current social power inequalities:

Few would deny the resistive weight of male rappers' critique of the so-called "peacekeeping" and "just mission" of urban police forces and the resulting redefinition of what constitutes violence, as well as which groups have the power to exercise hidden or institutional violence. At the same time rappers also tend to reinforce the male sexual domination of black women and confirm and sustain the construction of black women as objects and status symbols. ... These attacks on black women ultimately reinforce the social domination of black women and have no place in politically progressive struggles. Similarly, rap's commentary on alienating and racist educational structures and curricula clearly critiques dominant ideologies regarding the reasons and solutions for the crisis in public education, yet some rap artists' homophobic and anti-Semitic lyrics are neither progressive nor resistive (Rose 103-104).

And though other popular cultural expressions may be critiqued in a similar vein, this is not justification for Hip Hop's more regressive and hegemonic aspects. Instead, using Rose, I would suggest that rap, being so pervasive, is often under public attack so as to destabilize its more resistive elements. 
To be sure, Rose supports her claims of rap as a powerful political tool of criticism by engaging three politically explicit raps to lyrical analysis, namely: KRS-One's "Who Protects Us From You?"; L.L. Cool J.'s "Illegal Search," and Public Enemy's "Night of the Living Baseheads." KRS and L.L.'s texts are compared as critiques of police harassment and brutality against black males, while the PE text (with its related video also considered) is read as "a multilayered critique of the government, the police, the media, and the black bourgeoisie" (Rose 105). Rose writes that critique of the police force - and related racism, harassment, and brutality - form the core political agenda for most (black) male rappers:

In the Reagan and Bush era's war on drugs, urban police forces have been soldiers of war, and poor and minority communities are the enemy battleground. The antidrug war metaphor intensifies an already racially fractured urban America and labels poor minority communities an alien and infested social component and a hot spot for America's drug problem. The nature and character of this drug effort has collapsed categories of youths, class, and race into one "profile" that portrays young black males as criminals (Rose 106).

It is therefore notable that my work does not directly address such a topic. Indeed, I am not poor, a minority, or even American. In turn, lyrical analysis of my own work will be made with attention to such issues of identity as race, gender, sexual orientation, and socio-economic status - as well as to issues of what it is I may be working to critique (and how successful I may have been in doing so) - in relation to my own identity status. Though not necessarily embodying the powerful, my (self-)identity is certainly one marked by the body of the powerful: I am a well-educated, white heterosexual male from a working- to middle-class background. In turn, exploration of the possibility of social hierarchical inversions (and the functioning of such) is to be addressed, as is the possibility for subversion of what may be deemed the public transcript in a more general sense. The question of my contributing to the building of cultural bridges is here overriding. More 
specifically considering Rose (as well as Krims), the specific issue of race seems to here be of the greatest importance. Much has been written about rap as allowing for black cultural expression, black cultural subversion, and the formation of a black revolutionary identity; the question of my own performance - being a white rapper - must therefore be brought to the fore. My place in Hip Hop generally, and the functioning of my creative work in reference to Rose (as a starting point concerning such issues), shall thus be explored.

Certainly, as a kind of supplement to Rose's theses, I read with great interest Bakari Kitwana's Why White Kids Love Hip-Hop. Simply put, in his chapter entitled "Identity Crisis?: More Than Acting Black," Kitwana muses concerning white Hip-Hop participation by profiling various white participants in the culture (in a variety of capacities). In turn, it is Kitwana's contention that white people ("kids") are drawn to HipHop: because of a fascination with black culture; because of a disdain with white culture (or at least with white racist views); and as a means for rebellion:

Why do white kids love hip-hop? The answers are endless. But the further you dig into individual lives, the more layers of complexity you're likely to find. Race in America is complicated by many factors. Old racial politics and new racial politics collide with regional differences, personal experience, family history, pop culture and individual experience. Each person has a unique story that brought him or her to hip-hop. Looking at the micro-reasons as well as the macro ones help us make sense of a contemporary hip-hop scene in which a new generation is affected by America's racial history and in the process is constructing a new politics (Kitwana 78).

Engaging in self-analyses concerning the politics of my own creative work, I now hope to further explore and complicate a myriad of questions related to identity and Hip Hop culture. 


\section{COMMENTARIES}

"It's Hip-Hop music, it's good enough to speak for itself, and you gotta do right by it." - Mos Def, "What's Beef?"

As a general observation, all of my song's titles (as well as my album title and performative name) are written in lower case letters in reference to the work of my personal favourite poet, e.e. cummings. The word "Hip Hop" - as in the song title Hip Hop is dead - is the only word capitalized in my album's track list so as to show reverence to Hip Hop as culture; indeed, capitalization and spelling of the term is again made in accordance with the teachings of the Temple of Hiphop."

My album, the cashtro hop project, opens with a track entitled psycho (the prelude) (see Appendix 3.1 for a transcript of the song's lyrics). The song was originally meant to be my work's introduction, but after reasoning that an instrumental playing with the sound of a college marching band would be a more fitting choice for my album's proper opening, I chose to place psycho as a kind of prelude to the project as a whole (indeed, the track ends with the assertion, "this the prelude"). The instrumental backing for "psycho" is an adaptation of the theme song from Alfred Hitchcock's film of the same name and opens in a prolonged and dramatic manner (that would be familiar to most connoisseurs of the popular arts). Content-wise, this is a boasting or "toasting" rap; I here sought to display a kind of lyrical prowess through rapid diffusion of rhyming syllables. As an aside, I prepared for the writing of this song and the style of delivery I

11 The Temple, as part of its "Refinitions" (or redefined definitions) states that Hip Hop, being a culture, should therefore be capitalized. Also, the Temple holds Hiphop as a proper noun; "unless the term Hiphop is being displayed in an art presentation it should be spelled as one word beginning with a capital $H$-Hiphop." Finally, and most related to my designs, the Temple asserts that Hip Hop, spelled with two capitals, is the "phonetic spelling of Hiphop ... Writers are advised to use this spelling ... when educating the public." 
sought to impart by listening to the rapper Big Punisher and, more specifically, his "Dream Shatterer".

The album then opens in its more proper form with introduction: more knowledge (see Appendix 3.2 for lyrics). The introduction part of the song's title is in reference to my album (as a whole) being completed within an institutional, educational setting. Indeed, this is my "project" (in reference to the title of the album itself), and as such, is organized much like a formal essay: with both an "introduction" and "conclusion" encompassing the work-proper. "More knowledge" is to further position my work as related to the scholarly and is taken from the beginning of the song's verse: "more knowledge than college bands flipped." To be sure, the track's instrumental was purchased through a producer found on the internet, Mardah Beatz, at www.thebeattrader.com. I thought it a fitting sonic backdrop as it includes a sample of a college band "flipped" (as Mardah writes in his description of the beat) or sampled and remixed - again, note here the educational allusion. Content-wise, the song is again a show of braggadocio, for through it I sought primarily to demonstrate rhyming prowess. Referencing of "Moses," "scripture," and "hieroglyphics" was employed so as to position my work as of a venerable, distinguished, and significant nature; preparation for the writing of this opening track included a thorough listening to the work of the rapper Rakim, who often uses similar lyrical imagery. ${ }^{12}$ As well, I here employ a host of comic-book references, for I sought also to position my album as akin to a kind of adventure in popular culture. The song ends with the repeated spoken assertion, "love it or hate it, they can't take it" which is in direct reference to the album's fourth track, it's ok (which contains the chorus, "love it or they hate it, it's ok"). Certainly, I mean further to

12 See especially such Rakim tracks as "It's Been a Long Time" and "Guess Who's Back" from his album, The $18^{\text {th- }}$ Letter. 
convey through my closing speech that whether listeners enjoy or dislike my music, they can not take away or detract from the work that went into my project's completion.

My album's first full-length track, pain (see appendix 3.3 for lyrics), is to be one of its most reflective. The song was written in wake of the dissolution of a romantic relationship and argument with a friend. Further, serving as a preliminary piece prefacing my album's critique of Hip Hop, it (especially along with the album's following track), is to reflect my love-hate relationship with the culture (and its true positive, political versus cliched, mainstream manifestations). It could be said that it pains me to see that Hip Hop has, in the mainstream case, lost its political awareness and positive-cognizance. As an aside, the instrumental for pain was purchased online from LB Beats at thebeattrader.com.

Surely, it's ok (see Appendix 3.4 for lyrics) also functions, in one sense, as a boasting rap, and may therefore be viewed as an extension of the album's "prelude" and "introduction." Of note, the instrumental for it's ok was also purchased from an online website, www.donbeats.com. After researching various independent Hip Hop producers on the internet and listening to a wide-range of instrumental samples, I decided to purchase the beat in question not only for its commercial appeal, but also because I felt it conveyed a sound that I personally would be unable to imitate through my own production. Lyrically, I would suggest that the first two verses of it's ok are quite introspective: in the song's first verse I rap concerning a fight with a close friend (a male, notice use of the word "men"), and, in the song's second verse, I rap concerning a fight with someone with whom I had once had a romantic relationship (a female, notice use of the feminine pronoun). The third verse is more of a boasting rap, ending again (much like introduction: more knowledge) with a rapid diffusion of rhyming syllables; similar vocal delivery is also evident in the song's fourth (and final) verse. 
With the album's fourth track, combat jack (see Appendix 3.5 for lyrics), my project more pointedly enters its narrative proper. The song begins with a sample that assures that the piece is one of satire. As such, I take on the persona of "Combat Jack" and rap as a "gangsta," with content that is to reference the now-cliched material of the gangsta genre: glorification of guns and street violence, material wealth, and sexual accomplishments. Certainly, the song's instrumental is reminiscent of the Notorious B.I.G.'s "Dead Wrong," and while Biggie is indeed a favourite rapper of mine for his flow or delivery, I have often found it hard to reconcile a liking for his verbal skill with a dislike for some of his more explicit content - most specifically, his sometime glorification of street violence. Thus, combat jack is to serve as parody, especially in combination with the album's next track, my club song.

Again, my club song (see Appendix 3.6 for lyrics) was written so as to function satirically, though this track may be taken as much more playful than the last. So as to invoke a club atmosphere, the track opens imitating the sound of a large crowd, during which begins a beat that is intended to mimic the popular club songs of the day (most specifically, the instrumental from rapper J-Kwon's "Tipsy"). Much of the lyrical-content is here made in jest: I rap that I am "kidding though" after the insertion of a shot-gun effect; additionally, after being warned during the song's narrative that I have only a limited amount of time in which to perform, I counter: "but I just started my rhyme / gotta fit in chicks, this jewelery, money / cars, clothes, and some shit that's funny." My goal here is to again point to the cliched and formulaic content associated with the most pervasive of Hip Hop's cultural products - this time in association with so-called Hip Hop "club" culture. In turn, the song's lyrics reference a relatively large number of 
popular club anthems and other "classic" Hip-Hop tracks. ${ }^{13}$ As well, the song's chorus, which includes the lyric "insert here R. Kelly or Ashanti / Nate Dogg, Pharrell, Lil Jon, Beyonce" is also meant to draw attention to the formulaic content of many popular rap tracks; "club" hooks often use such performers as the immediately aforementioned popular (American) artists so as to strengthen a given work's commercial appeal.

Particularly taken in tandem, combat jack and my club song are meant to critique the popular view and current state of much (popular) Hip-Hop music. Thus, my album's sixth song, Hip Hop is dead (see Appendix 3.7 for lyrics), begins with a skit in which I receive news that the culture (here personified) has passed away. Lyrically, the song's first verse deals with my discovery of such information (through the deciphering of a code), my lamenting of Hip Hop's death, and my being called to a secret location. The song's second verse documents my traveling to the secret location and, in the track's third verse, I "arrive at my destination" (as I rap in the verse's opening), and witness a scene in which onlookers are said to be crying beside a coffin. My rap then asserts, "all of sudden ... they [the onlookers] all start to spit the hook," and the third verse consequently ends with the assertion that this was a "secret society, they just tryin' me" - or that Hip Hop is not dead, but that instead, such news was falsified as a ruse so as to call me (or my character) into a private meeting with Hip Hop's "forebears." The track's final verse then comments on the "power of the music" and how it should be used in a "positive" manner with due respect to the "ancestors" of the culture. Content-wise, Hip Hop is dead may be viewed as having commonalities with such tracks as Jeru the Damaja's "One Day," in which the

13 Examples include: The Alkaholiks' "Off The Wall"; Jeru the Damaja's "Ya Playin' Yaself"; Busta Rhymes" "Break Ya Neck" and "Make it Clap"; The Notorious B.I.G.'s "Hypnotize" and "Party and Bullshit"; N.E.R.D.'s "Frontin"'; Noreaga's "Superthug," "Grimey," and "Nothin"”; Fabolous' "Can't Deny It"; Chingy's "Right Thurr"; J-Kwon's "Tipsy"; Destiny's Child's "Bootylicious"; Outkast's "The Way You Move"; Puff Daddy's "Bad Boy for Life"; Juvenile's "Back That Azz Up"; Mos Def's "Ms. Fat Booty"; Ludacris' "Stand Up"; Missy Elliot's "Get Ur Freak On" and "Sock It 2 Me"; and 50 Cent's "In Da Club." 
song's main protagonist (Jeru) is called to rescue "Hip Hop" (again personified) from such commercial figures as Puff Daddy and Suge Knight. Also, as a kind of extended story-telling piece, Hip Hop is dead may be seen as akin to such songs as Saukrates' "The Professional" another inspiration for the writing of my track.

As consequence of my album's previous four songs, the cashtro hop project's eighth track, razzle dazzle (see Appendix 3.8 for lyrics), begins with my spoken comment, "this is all like a bad dream." Opening with the sound of solitary footsteps, a slamming door, and a chorus of screams, my intention was for this piece to create a nightmare-like sonic climate in which I sought to deliver similarly nightmarish lyrical imagery. In reference to Hip Hop is dead and its depiction of the culture as deceased, razzle dazzle's rap begins with the line, "rise from the dead." Employing such terms as "scariest," "chaos," and "satanic"(from the song's first verse), "massacre," "torture," and "rapture" (from the song's second verse), and "horror," "screaming," and "confusion" (from the song's third verse), lyrical content may here be marked as lexically cohesive and seeking to invoke in the listener feelings of fright or fearfulness. In turn, a number of the track's bars begin with my lines "punched in": my aim was to create a "second" and more detached voice in efforts to reinforce the song's overall lyrical imagery. The track also ends with the spoken comment "I gotta wake up"; again, this is to reinforce the preceding imagery as "nightmarish" and to suggest that I (or my album's character) is asleep - thus the fantastic scenario of the work's following piece.

Similar to razzle dazzle, my album's ninth song, out the box (see Appendix 3.9 for lyrics), also employs a "second" voice; still, in this instance, my intention was to utilize not an effect of detached or nightmarish timbre, but rather one of the "other-wordly" or "alien." As conveyed in the song's spoken opening, I - or my character - has been abducted while sleeping 
by a group of extraterrestrials for, as they put it, training purposes. Certainly, though such a scenario may readily be viewed as outlandish or even silly, it should be noted as one not without precedent: inspiration for out the box was first encountered upon my viewing of a video documenting Parliament Funkadelic's "mothership" tour. Indeed, there has been a range of (black) musics that have ascribed to such imagery. I thus rap of controlling "the planets and suns," with ad-libs and the song's chorus being done by the track's second or alien voice. Also, much of the imagery here used is of Jesus as Christ (another "son"), with my character consequently working to position his skill as God-like. Moreover, (Christian) religious imagery is used so as to set-up my "return" to earth (in the album's next track); to be sure, with out the box I rap of my (character's) impending "resurrection" and subsequent "ascension." By track's end, the aliens are figured as now looking favourably upon my skill as a rapper - and therefore demand that I take such prowess back to my own planet (in the song's spoken closing).

The album's next track, perfume (see Appendix 3.10 for lyrics), is to be the "resurrection" and "ascension" of which I speak in the preceding piece. Also tying this track to the one before it, the first verse of perfume includes the phrase, "it is the extraterrestrial, messagin' you from a shuttle / bust ya bubble out the rubble it is the non-subtle and a," which was rapped (in somewhat modified form) by my "alien" voice in the opening of out the box. I view perfume as very much another "boasting" rap, again also employing (Christian) religious references: "Isaiah 61:1," and the phrase, "reach 'em, preach like an evangelist." Taking the advice of my alien captors in out the box, perfume's chorus asserts that I will not allow my "spirit" to be "bottled-up like perfume."

My tenth track, american justice I (see Appendix 3.11 for lyrics), is likely (in conjunction with the song's later sequel) the album's most pointedly political. In the broadest 
sense, the track is against abuses of power. The piece is an adaptation and continuation of a poem I had previously written for an online journal, and in both the earlier work of poetry and the track itself, I seek to criticize the United States' cultural imperialism in particular, as well as globalization more generally; this is a story of the "haves" and "have nots," of how "millions a day be facin' down mortality."

The next track may be viewed as, along with pain, (arguably) the album's most introspective piece. To be sure, i eternal (see Appendix 3.12 for lyrics), was actually the first track that I produced for the album; this is to be my "journal" (as I rap in the song's chorus), and in it I seek to emote conflicting feelings of sorrow and passion from the perspective of both a man (in the song's first verse) and a woman (in the song's second). After critiquing more popular current Hip Hop music in the album's first half, this track is to represent (while avoiding more pointed and dangerous moral judgments) the culture's more mature and positive aspects. Sonically, i eternal was wholly created by myself and my producer by employing a wide range of live samples.

With american justice II (see Appendix 3.13 for lyrics), I (along with another emcee) continue to critique what we see as the United States' abuses of power; indeed, a portion of both choruses in the "american justice" series employ the lines, "american justice got us seein' star clusters / gotta fight up all the might that ya can muster." Stylistically, the track is a departure from the rest of the album as I am trading lines back and forth with another emcee, Johnny Frederick - who was also featured on combat jack and who (as will be discussed) is featured on conclusion: more power. As an aside, rapping as a duo has a long pedigree in Hip Hop music, and I sought to enlist the services of another rapper in order to give the album greater sonic diversity. 
My project's fourteenth track, and it goes like this... (see Appendix 3.14 for lyrics), may be marked, much like the already described Hip Hop is dead and (as will be discussed) the album's final track, one day, as a storytelling piece, or one in which a tight (and chronological) narrative focus is kept. To be sure, this corpus of songs - Hip Hop is dead, and it goes like this..., and one day - are all pieces with a moral. Indeed, and it goes like this... is to be a continuation of the didactic turn taken by the cashtro hop project beginning with Hip Hop is dead (and continued with the "american justice" pieces - and, to some extent, with $\mathbf{i}$ eternal and pain). Here, a scenario is set: I am telling a story to a friend (who is to have composed the beat) detailing the day in the life of a young man who is enamored with Hip Hop culture. In short, the main character of the story stops to give money to a homeless man, in turn missing the bus (for which he now is without means to pay the fare). As a result of this twist of fate, the main character then meets a girl waiting at the nearby traffic-light whom he befriends, invites to a Hip Hop show at which he is performing, and eventually becomes romantically involved. The friend who is listening to my story then relates, in the song's chorus or hook, that my rap is "corny" - and so, I then begin what I call my "alternate version." In the song's second half, the story is retold in modified form: here the young male protagonist, ignoring the homeless man, uses his cell phone to call a friend who owns a range rover; the young man is then picked-up by his friend, causing the "queen at the light" to be "just another sight." Surely, this is an example of a story with an ethical - again, the use of Hip Hop for didactic purposes.

With free-thought (see Appendix 3.15 for lyrics), my album then takes a turn, lyrically, toward the more abstract. Content here is to convey stream-of-consciousness and is, in reality, a collection of disparate parts from a number of verses I had written; this was to be a kind of "venting" track before my album's conclusion. Indeed, it is with the album's sixteenth track, 
conclusion: more power (see Appendix 3.16 for lyrics), that I reach the end of my narrative proper. While my introductory song was a call for further knowledge, this song is a call for further power in the round. The two pieces (my "introduction" and "conclusion") are linked both thematically and sonically: my verse for conclusion: more power begins with a referencing of the chorus from introduction: more knowledge; as well, the instrumental for this concluding piece was also purchased (like that used for my introductory track) from Mardah Beatz (through www.thebeattrader.com). Both introduction and conclusion may be marked as boasting tracks that seek to discredit those that would criticize my music. This concluding song also ends, fittingly enough, by detailing the meaning behind my emcee (or character's performative) name, cashtro hop: "cashtro hop is the name i pray like / believe emcee's a god words are clay right / control the mic like friends be callin' me / by my surname a son an oddity." Because of my surname, many of my friends simply call me "Cash," and so I wanted this to be part of my musical identity. The name "cashtro" is, of course, a reference to Fidel Castro, whom my personal favourite emcee, Jeru the Damaja, has referenced a number of times (espousing his ability to "control the mic like Fidel Castro"). "Hop" is a reference to my self-identifying and performing as the "offspring" - or, in this instance, "son" - of Hip Hop culture.

Finally, as a "bonus" track which I included as part of my album but placed outside of its more strict narrative structure, one day (Appendix 3.17 for lyrics), is my work's final piece. It is very much an extended storytelling track chronicling the relationship of two men from childhood through adolescence and into adulthood. Inspiration for the piece, content-wise, stemmed from my personal relationship with the co-producer of my work. Stylistically, the track is indebted to a song by KRS-One entitled "False Pride" that appeared on his Sneak Attack album; in it, KRS tells a didactic or instructive story using the same end-rhyming syllable throughout. My song, 
one day, works in a similar fashion, with a musical backdrop that is likely the album's most complicated and most varied. 


\section{(SELF-)ANALYSES}

Taking my reflective and analytic commentaries as object for study (along with the album itself), my (self-)analyses section is to further employ the above outlined, three-pronged theoretical framework as a means to continue exploring issues related to (self-)identity and the completion of my creative project. I here strive to bring to bear those issues not already more fully explored through the preceding combination of theory and commentary. This is to be a further fusion of theory and practice, of abstraction and the concrete.

In light of Goffman's discussion of the individual's own belief in his or her performance, my personal take on my creative work, especially in the early stages of the recording of my project, could very much have been characterized as cynical. I would suggest that much of this cynicism stemmed from feelings of self-doubt; I questioned whether my skill as an emcee was good enough, whether my production would convey thorough enough technical prowess, and whether my identity would allow for the staging of a convincing enough performance to wouldbe audiences. It was only after I allowed others to sample rough mixes of my creative work and after they responded favourably - that some of my initial apprehension was allayed.

Certainly, it was only after I felt that at least a small portion of my would-be audience would be convinced of my ability as a rapper that self-cynicism approached sincerity, pessimism approached anticipation, and insecurity approached nerve.

I stopped (for the most part) feeling that people would see my performance as mere "front" (to borrow from Goffman), but rather as an authentic expression of Hip Hop culture. Interestingly enough, Goffman's consideration of performances as "front" has an especially intriguing relation to Hip Hop. To "front" in Hip Hop vernacular is to attempt a false persona, to act like you are someone else, to put on pretenses; "fronting" is a negative, and a number of rap 
songs warn listeners, "don't front."14 Taking Goffman, my performative persona may be discussed (below, using Krims and Rose) in terms of such characteristics as sex, race, speech patterns, and the like. In more general terms (and related to Goffman's discussion of "abstractness" and "generality"), I stated that performers of various musics (including Hip Hop) often strive for both uniqueness and similarity. In this light, I have worked to create lyrical content unlike other writers, a vocal delivery unlike other performers, as well as unique instrumental tracks and song concepts. Still, as was further evident in my commentary section, I sought also to create a product that was, in some aspects, akin to the work of other of Hip Hop's musical producers (Big Punisher, Rakim, and the Notorious B.I.G., amongst others). I therefore sought to fit into the genre of Hip Hop music and, in a larger context, to fit into Hip Hop culture. In essence, I worked to create a specialized and unique routine in order to stand-out, while also working towards the presentation and maintenance of a social persona that would fit well with the very loosely-defined parameters of what constitutes "Hip Hop."

Of course, Hip Hop - as both culture and music - is difficult to strictly define. Murray Forman writes that the now commonplace term, hip-hop nation, is "employed in reference to a relatively coherent social entity founded in shared interests or values and collective practices that bind constituents within a symbolic unity" (5); he continues: "This 'nation' is not precisely placed, lacking agreed-upon boundaries or other demarcating features, but is, in its fuller sense, akin to Benedict Anderson's (1983) concept of 'imagined communities'" (5-6). Immediately evident, my album's introduction evidences my working towards what Goffman would term "dramatic realization"; simply put, I am attempting to confirm to others that my performance (that my "front") is especially significant. As stated in my commentary section, my introduction

14 For more on the term "front" as it is used by Hip-Hoppers, see www.urbandictionary.com. 
is titled "more knowledge," thus seeking to convey that my work is of a scholarly nature; also, I rap of "Moses," "scripture" and "hieroglypics," thus seeking to portray my work as venerable, distinguished, and significant. I have attempted to present an idealized version of my rapping ability to an (imagined) Hip Hop audience. My performance is necessarily socialized and works to exemplify the officially accredited values of (what I would suggest is a plurality of) Hip Hop culture(s). Overall then, I am striving for both abstractness (to set my creative work apart from others) and generality (so as to have my work accepted by an imaginary Hip Hop audience). I am seeking membership as a performer of the Hip Hop Nation by simultaneously conforming or "fitting-in" (with tracks akin to some of the culture's most popular musical producers) and by being different (by, for instance, acknowledging my educational status).

Related to Goffman's commentary on the maintenance of expressive control, my greatest personal fear surrounding the consumption of my creative project concerned the track combat jack. Certainly, I did not want my intent for the song to be misinterpreted or misconstrued. I was here working to parody the gangster genre of Hip Hop music, or the caricatured style of rap analyzed by Krims. In a sense then, I am also making light of my own position as rapper, for I am certainly not gangsta. But, as is often the case with parody or satire generally, my fear was (and still is) that listeners would not realize the track's intent. It was because I sought to control my presentation and maintain my expressive control that I added a kind of warning to the beginning of the track ("kids, this is an example of satire, of parody, please use caution") in efforts to overtly state my intentions for the song. The piece - especially in tandem with my club song - thus functions as resistance to the domination of popular Hip Hop products.

I am working to - borrowing from Krims' commentary on James Clifford - appropriate and revise Hip Hop's most pervasive forms (in the present), with an eye to changing the culture's 
landscape (in the future). Additionally, I could be said to be working towards resisting the commercial or mainstream in order to fit in with the underground or authentic. Put simply, I am staging my identity in opposition to the dominating alternative. I am "keeping it real" by acknowledging that for me to put on the persona of a gangster would be mere front or fake. I am not working to fashion a black revolutionary identity like that of Ice Cube (which is impossible), nor am I seeking to create some kind of white revolutionary identity. I am not attempting to work against blackness in any sense, but am merely attempting to foster a revolutionary identity in opposition to what I see as inauthentic or negative Hip Hop. Still, like Cube, who sees his music as primarily functioning for didactic purposes, I have outlined how I too have sought to create not just entertainment, but education. These two pieces especially - combat jack and my club song - may consequently be viewed as motivated signifying (to again appropriate Henry Louis Gates Jr.), for I work to both quote and trope an element of cultural production in order to critique it. By the end of combat jack, I have commented that I "already got flow, better hope my lyrics ebb," or that while such musics may be entertaining, their messages are potentially damaging - and that there are surely alternatives (within the culture's musics).

My creative work, then, is to stand as an alternative to the commercial or mainstream. I seek to speak directly to the Hip Hop community and - akin to Tricia Rose's assessment of Public Enemy - mount a popular cultural stage while simultaneously functioning as a means for social criticism (though, unlike PE, not in a strictly racial sense). I have worked to present a product and persona void of real sexism, misogyny, or homophobia, while operating within Hip Hop's conventions and continuing to extend them beyond an African-American focus. Further, I have done so within an institutional setting, thus challenging notions of how Hip Hop may be studied, and notions of what actually constitutes a given (authentic) Hip Hop product. 


\section{CONCLUSION}

While Hip Hop itself has a long history that may be traced through to ancient African oral traditions and cultures, Hip Hop studies is a growing field within the university, encompassing a multitude of concerns and approaches. The presentation of artistic self-identity within Hip Hop culture undoubtedly presents yet another fruitful area for scholarly inquiry that is multi-layered, allowing for academics to think about, discuss, comment upon, address, and explore larger cultural issues. My project is to first serve as a framework through which academics may concern themselves with such issues and, more particularly, through which academics involved with Hip Hop culture may come to critically examine their own roles, their own selves. Of course, greater work on this topic may (and, as is my contention, should) be undertaken. I have here dealt primarily with lyrical presentation - and on a recorded plane. Presentation as it relates to live Hip Hop performance (and, indeed, all of the culture's performative elements) could be studied; as well, analyses of Hip Hop's accompanying visual (marketing-related) elements album cover art and website design - could further be considered. To be sure, I find it surprising that such analyses are not often made - if not as self-concerned, then as other-concerned.

In turn, I feel compelled to stress Erving Goffman's text on self-presentation as a welldeveloped study that may be related to Hip Hop (performative) culture with the richest of results; this is a call for his theories to be further applied to discussions and analyses of the culture at hand. As well, the work of Adam Krims - and other such musicologists writing on Hip Hop may be noted as (while possibly difficult to comprehend for those not more thoroughly versed in musical theory) able to give a more grounded stance to those cultural theorists writing on rap musics; this is a call for those critiquing the culture to actually attend to its output on a deeper and more appropriate level. And so, with Tricia Rose and other trailblazing Hip Hop academics 
as a foundation, further analyses of the culture, and what it means for (young) people immersed within it (especially Hip Hop's performers) - how they occupy, play with, maintain, and traverse various identity roles - should surely be undertaken.

My commentary and (self-)analyses have shown that I strove to present an identity that is in line with what I have deemed to be the the most true and positive aspects of Hip Hop culture. I have sought to create a product against the cliched and formulaic, and therefore necessarily outside of the mainstream. Still, I have sought also to create a product that would regularly be deemed "Hip Hop" (by those purveyors of the culture) by presenting myself as one with a thorough knowledge of - or as one within - the culture. Interesting will be, in light of Krims and Rose - who also discuss rap identities in terms of those with institutional power - the academy's reception to my project. 


\section{APPENDICES}

\section{Appendix 1}

\section{The Hiphop Declaration of Peace}

Available: $\langle$ http://templeofhiphop.org/index.php?option=com_content\&task=view\&id=64\&Itemid=39>

This Hiphop Declaration of Peace guides Hiphop Kulture toward freedom from violence, and establishes advice and protection for the existence and development of our Hiphop community. Through the overstandings of this Hiphop Declaration of Peace, we establish a foundation of health, love, awareness, wealth, peace, and prosperity for ourselves, our children and their children's children, forever.

For the purpose of establishing a respectable international framework by which Hiphop Kulture may achieve and contribute to a lasting peace in the world, we - the founders, pioneers, inventors, artists, photographers, authors, teachas, and other kultural contributors of Hiphop Kulture - ordain and decree the manifestation of this Hiphop declaration of Peace.

That Hiphop Kulture may come to know, and act upon, its true intention, meaning, and purpose, we - the B-Boys, B-Girls, Emcees, DeeJays, Writers, Beatboxers and other legitimate contributors to HipHop Kulture - have united on this day (May 16, 2002), at the United Nations headquarters in New York, to document, establish, fulfill, and promote the vision of Hiphop as an International kulture for peace and prosperity.

For the clarification of Hiphop's meaning and purpose, or when the intention of Hiphop is questioned, or when disputes between parties arise, Hiphoppas shall have access to the advice of this document, the "Hiphop declaration of Peace," as guidance, advice, and protection.

\section{First Principle}

Hiphop (Hip'Hop) is a term that describes our independent collective consciousness. Ever growing, it is commonly expressed through such elements as Breakin, Emceein, Graffiti Art, Deejayin, Beatboxin, Street Fashion, Street Language, Street Knowledge and Street Entrepreneurialism. Wherever and whenever these and future elements and expressions of Hiphop Kulture manifest; this Hiphop Declaration of Peace shall advise the use and interpretation of such elements, expressions and lifestyle.

\section{Second Principle}

Hiphop Kulture respects the dignity and sanctity of life without discrimination or prejudice. Hiphoppas shall thoroughly consider the protection and the development of life, over and before the individual decision to destroy or seek to alter its natural development.

\section{Third Principle}

Hiphop Kulture respects the Laws and agreements of its culture, its country, its institutions and those with whom it does business. Hiphop does not irresponsibly break Laws and commitments.

\section{Fourth Principle}

Hiphop is a term that describes our independent collective consciousness. As a conscious way of life, we acknowledge our influence on society, especially on children, and we shall forever keep the rights and welfare of both in mind. Hiphop Kulture encourages womanhood, manhood, sisterhood, brotherhood, childhood and family. We are conscious not to bring any intentional disrespect that jeopardizes the dignity and reputation of our children, elders and ancestors. 


\section{Fifth Principle}

The ability to define, defend and educate ourselves is encouraged, developed, preserved, protected and promoted as a means toward peace and prosperity, and toward the protection and the development of our self-worth. Through knowledge of purpose and the development of our natural and learned skills, Hiphoppas are encouraged to always present their best work and ideas.

\section{Sixth Principle}

Hiphop Kulture honors no relationship, person, event, act or otherwise, wherein the preservation and further development of Hiphop's culture, principles and elements are not considered or respected. Hiphop Kulture does not participate in activities that clearly destroy or alter its ability to productively and peacefully exist. Hiphoppas are encouraged to initiate and participate in fair trade and honesty in all negotiations and transactions.

\section{Seventh Principle}

The essence of Hiphop is beyond entertainment: The elements of Hiphop Kulture may be traded for money, honor, power, respect, food, shelter, information and other resources; however, Hiphop and its culture cannot be bought, nor is it for sale. It (Hiphop) cannot be transferred or exchanged by or to anyone for any compensation at any time or at any place. Hiphop is not a product. Hiphop is the priceless principle of our self-empowerment.

\section{Eighth Principle}

Companies, corporations, non and not-for-profit organizations, as well as individuals and groups that are clearly benefiting from the use, interpretation and/or exploitation of Hiphop and the expressions and terminologies of Hiphop are encouraged to commission and/or employ a full-time or part-time certified Hiphop specialist to interpret and answer sensitive cultural questions regarding the principles and proper presentations of Hiphop's elements and culture relative to businesses, individuals, organizations, communities, cities, as well as other countries.

\section{Ninth Principle}

May 3rd is Rap Music Day. Hiphoppas are encouraged to dedicate their own time and talent to selfdevelopment and for service to their communities. Every third week in May is Hiphop Appreciation Week. During this time, Hiphoppas are encouraged to honor their ancestors, reflect upon their cultural contributions and appreciate the elements and principles of Hiphop Kulture. November is Hiphop History Month. During this time Hiphoppas are encouraged to participate in the honoring of Hiphop's history and historical cultural contributors.

\section{Tenth Principle}

Hiphoppas are encouraged to build meaningful and lasting relationships that rest upon love, trust, equality and respect. Hiphoppas are encouraged not to cheat, abuse, or deceive their friends.

\section{Eleventh Principle}

The Hiphop community exists as an international culture of consciousness that provides all races, tribes, religions and styles of people a foundation for the communication of their best ideas and works. Hiphop Kulture is united as one multi-skilled, multi-cultural, multi-faith, multi-racial people committed to the establishment and the development of peace. 


\section{Twelfth Principle}

Hiphop Kulture does not intentionally or voluntarily participate in any form of hate, deceit, prejudice or theft at any time. At no time shall Hiphop Kulture engage in any violent war within itself. Those who intentionally violate the principles of this Declaration of Peace or intentionally reject its advice, forfeit by their own actions the protections set forth herein.

\section{Thirteenth Principle}

Hiphop Kulture rejects the immature impulse for unwarranted acts of violence and always seeks diplomatic, non-violent strategies in the settlement of all disputes. Hiphoppas are encouraged to consider forgiveness and understanding before any act of retaliation. War is reserved as a final solution when there is evidence that all other means of diplomatic negotiation have failed repeatedly.

\section{Fourteenth Principle}

Hiphoppas are encouraged to eliminate poverty, speak out against injustice and shape a more caring society and a more peaceful world. Hiphop Kulture supports a dialogue and action that heals divisions in society, addresses the legitimate concerns of humankind and advances the cause of peace.

\section{Fifteenth Principle}

Hiphoppas respect and learn from the ways of Nature, regardless of where we are on this planet. Hiphop Kulture holds sacred our duty to contribute to our own survival as independent, free-thinking beings in and throughout the Universe. This planet, commonly known as Earth, is our nurturing parent and Hiphoppas are encouraged to respect Nature and all creations and inhabitants of Nature.

\section{Sixteenth Principle}

Hiphop's pioneers, legends, teachas, elders, and ancestors shall not be inaccurately quoted, misrepresented, or disrespected at anytime. No one should profess to be a Hiphop pioneer or legend unless they can prove with facts and/or witnesses their credibility and contributions to Hiphop Kulture.

\section{Seventeenth Principle}

Hiphoppas are encouraged to share resources. Hiphoppas should give as freely and as often as possible. It is the duty of every Hiphoppa to assist, whenever possible, in the relief of human suffering and in the correction of injustice. Hiphop is shown the highest respect when Hiphoppas respect each other. Hiphop Kulture is preserved, nurtured and developed when Hiphoppas preserve, nurture and develop one another.

\section{Eighteenth Principle}

Hiphop Kulture maintains a healthy, caring and wealthy, central Hiphop guild - fully aware and invested with the power to promote, teach, interpret, modify and defend the principles of this Hiphop Declaration of Peace. 


\section{Appendix 2}

\section{Ice Cube Lyrical Transcript}

A Note Concerning Appendix 2: Lyrics of Ice Cube's "The Nigga Ya Love top Hate" are here transcribed as they appear in Adam Krims' Rap Music and the Poetics of Identity, pages 100-102, save for two notable changes: (1) while Krims numbers each musical measure and marks them off by placing each on a new line, I have here chosen to merely delineate bars using the " $/$ " mark; (2), having done away with Krims' numerical notation, I have here bolded the song's choruses (just as my own refrains were bolded in Appendix 1) for easier reference.

\section{Ice Cube's "The Nigga Ya Love to Hate"}

I heard / Pay back the muthafuckin' nigga, that's / Why I'm sick of getting treated like a goddamn / Stepchild, fuck a punk 'cause I ain't him / You gotta deal with a nine-double-m, / The damn scum that you all hate, just / Think, if niggas decide to retaliate / And try to keep you from runnin' up, I never / Tell you to get down, it's all about comin' up / So why did u go and ban the AK? the / Shit wasn't registered any fuckin' way, / So you better duck away, run, and hide out / When i'm runnin' real slow and the light's out, / 'Cause I'm about to fuck up the program, / Shootin' out the window of a drop-top brougham, / Well, I'm shootin', let's see who drops, the / Police, the media, or suckas that went pop, / The muthafuckas that say they too black, / Put 'em overseas, they be beggin' to come back, / And sayin' peep about gangs and drugs, you / Wanna sweep a nigga like me up under the / Rug, kickin' shit called Street Knowledge / Why are more niggas in the pen than in college?/ Because of that line, I might be your / Cell-mate, from the nigga you love to hate! / [group, shouting:] Fuck you, Ice Cube! [Ice Cube, rapping:] Yeah! Ha, ha! / It's the nigga you love to hate! / [group, shouting:] Fuck you, Ice Cube! [sample:] Anyway, yo' mutha / Warned ya about me. [Ice Cube, rapping:] It's the nigga you love to hate! / [sample, black man:] Yo, you ain't doin' nuthin' positive, you ain't - you ain't doin' / Nuthin' positive about it! What you got to say for ya- / Self? [Ice Cube, rapping, voice heavily processed:] You don't like how I'm living? Muthafuck you! / [Ice Cube, rapping, voice as before:] Once again, it's / All in the muthafuckin' cycle: 'Ice / Cube you bitch killa, cop killa,' / Yo! Runnin' through the lies like bruthas, no / Pot to piss in, I blew my piston, / Now who do you love to hate? / 'Cause I talk shit and down the eightball, / 'Cause I don't break, you beg and I fall off, / You cross colour, might as well cut them balls off, / You git'cha ass ready for the lynching, / Da Mobb is droppin' common sense in / We'll take and up here we'll shake any / Tom, Dick, and Hank, and git'cha ass / Thinkin' not about how right and wrong ya live, but how / Long ya live, I ain't with the bullshit, / I meet mo' bitches, mo' hoes / Don't wanna sleep, so I keep poppin' No-Doz, / And tellin' young people what they gotta know, / 'Cause I hate it when niggas gotta lay low and / If you're locked up, I gotta get my style in / From San Quetin to Riker's Island, / We got 'em afraid of the funky shit / I like to clown, so pump up the sound in your / Jeep, make the ol' ladies say, "Oh my / God, hey, it's the nigga you love to hate!" / [group, shouting:] Fuck you, Ice Cube! [Ice Cube, rapping:] Yeah, c'mon, / Fool! It's the nigga you love to hate! / [group, shouting:] Fuck you, Ice Cube! [Ice Cube, rapping:] Yeah, what up, / Punk? It's the nigga you love to hate! / [Woman, shouting:] Yo, what the fuck you think you are, callin' us bitches? / We ain't all that! That's all I hear, "bitch, bitch"! / I ain't nobody's bitch! [Ice Cube, rapping:] A bitch is a / [group shout:] HOE! [spoken voice:] train [Ice Cube , rapping:] Soul / Train done lost they soul, just / Call it "Train" 'cause the bitches look like hoes, / I see a lot of others, damn! / It all hurts, look like a Bandstand, / You ask me, do I like Arsenio? / About as much as the Bicentennial, / I don't give a fuck about dissin' these / Fools, 'cause they all scared of the Ice Cube, / And what I say, what I betray, and / All that, and they ain't even see a gat, / I don't want to see no dancin', I'm / Sick of that shit - listen to the hit! 'Cause / Y'all ever 
look and see another brotha on the / Video, tryin' to outdance each other? / I'm-a tell T-Bone to pass the bottle, / And don't give me that shit about "role model" / It ain't wise to chastise and preach, / Just open the eyes of each, 'cause / Laws are made to be broken up, what / Niggas need to do is start lookin' up, and / Build, mold, and fold themselves into/ Shape, of the nigga you love to hate! 


\section{Appendix 3}

\section{Creative Project Lyrical Transcripts}

A Note Concerning Appendix 3: Because discussion and investigation of my self-presentation very much centers around lyrical analysis, I have decided to include below a transcript of those lyrics included as part of my audio project. Each musical bar has been delineated with a "/" mark and ellipsis here employed to indicate an absence of lyrics for a space of approximately one half measure. Lyrics in bold type are part of a given song's chorus (or "hook"), while italics are used to signal lyrics that are either spoken (as part of a given song's "skit") or recited by another rapper or singer. As well, lyrics within " $\infty$ " marks indicate "punch-ins" or ad libs recorded either by myself or others as add-ons to a given song's main lyrical narrative. Of course, while consideration of a given performance in the round (especially concerning the performance of Hip Hop music) would look to not just what one says, but how one says it - still, attention to lyrical content is of paramount importance.

Appendix 3.1

"psycho (the prelude)"

instrumental take ya fates like bates stab when he / mentally tragically murder thee lyrically / wittily i label these cats they can't see / brainly react like atoms to bomb psalms verily / scarily experimental never ever accidental / it's the intercontinental flowin' showin' transcendental / 'gain game mental gainin' rainin' monumental / into me askin' me seein' tempermental / like ventricle closin' knowin' fate chosin' / tempt take frozen hang like my clothes and i / rosin' dead like Christ-like more like / flow like 'tro like go and score and so like / or like sun tzu who one two slay men / word images cause damagin' they kin / word visages pause bandagin' slayed men / word messages i passionate take then / psycho flip flow cashtro hypno / what they can't know what they can't know / psycho flip flow cashtro hypno / what they can't know what they can't know / what they can't know $i$ burned like candles $i$ / yearned inside my eye spurned inside the try / earned inside the die voices multiply / choices i supply fiends that wanna fly / fiends that wanna fly higher i defy / voices multiply voices multiply / what they tryin' to hide hide like homicide / life or death $i$ ride $i$ and $i$ beside / $i$ will $i$ 'll provide $u$ and come through / step my rep like what they tryin' to do / what the what the wha' what they want $u$ / what $u$ can't understand $\mathrm{i}$ come thru / this the prelude so please be smart / before a bleeding heart gets torn apart / before the beating start i am i am this / great like take like i am understand this / this the prelude so please be smart / before a bleeding heart gets torn apart / before the beating start $\mathbf{i}$ am $\mathbf{i}$ am this / great like take like $i$ am understand this / ran this ran this / run this run this / ran this ran this / run this run this

\section{Appendix 3.2}

"introduction: more knowledge"

this ain't no Hip-Hop this is God-damn lit-rock / cats wanna talk shit to me for spittin' like / this ain't no Hip-Hop this is God-damn lit-rock / cash wanna hawk this i'ma bet on my life / this ain't no Hip-Hop this is God-damn lit-rock / cats wanna talk shit to me for spittin' like / this ain't no HipHop this is God-damn lit-rock / cash wanna hawk this i'ma bet on my life / more knowledge than 
college bands flipped the flow is / words manifested why you chose this / low know the temperature prose froze kids / couldn't part me and this mic if you were moses / compose this like scrolls but never dead see / cashtro yes i'm nice still they need me / read me like i flipped they whole scriptures / pictures like it's hieroglyphics hit ya / stricture nah attach me to ya dreams / i rip 'em up cut 'em up like i'm wolverine / a triple-beam never seen like the nightcrawler / hotter than he goku sittin' up in a sauna / who wanna get critical check the intricate / rhyme profile's more styles than blood syndicate's / into it usurp the mayor sin city and / witty gritty $i$ be on a balcony committee says it's on / this ain't no Hip-Hop this is God-damn lit-rock / cats wanna talk shit to me for spittin' like / this ain't no Hip-Hop this is God-damn lit-rock / cash wanna hawk this i'ma bet on my life / this ain't no Hip-Hop this is God-damn lit-rock / cats wanna talk shit to me for spittin' like / this ain't no Hip-Hop this is God-damn lit-rock / cash wanna hawk this i'ma bet on my life / love it or hate it they can't take it / love it or hate it they can't take it / love it or hate it they can't take it / and i'm gone...

\section{Appendix 3.3 \\ "pain"}

tuesday may twenty-three now i see / this light inward me out of spite this night decree / i'm sick of this fed up <fed up $>$ out of bed i get up < $<$ get up $>/$ read up <read up $>$ let up <let up $>$ never now i set up < set up $>$ / life hungover ma on rum and amaretto <retto $>$ / so i get low let go past my motto <motto $>$ / but $\mathbf{i}$ look back back stop and reminisce / over the track this my wish death my kiss / miss indecisive now i'm cold as ice is / crisis christ this make me feel like isis / divine the sexes rhyme the sun shine / battlin' God tryin' to take time after time / but she fight back back wanna complicate that / great stake my fate soul confiscate rap / too late wait with dreams unfulfilled and / willin' mind is frettin' cos the heart is still fillin' / the pain's like every single day like / he can't change like what should he gain like / life is like this life is like this / pain is like this you gotta fight this / the pain's like every single day like / he can't change like what should he gain like / life is like this life is like this / pain is like this you gotta fight this / very next day wake-up it's all the same hid / underneath this man the gun i can't change it / rain fallin' face it the basement place it / middle of my stomach very own encasement / hated stayin' behind me's the timely / twenty-four the grimy watch sharp shiny / tiny in the class then tiny in the dash / truth be told's leavin' the world when i pass / last on the nightly every time you fight me / rightly justified shake handle tightly / might be like i'm the culprit the pulpit / lit up like the preacher enraged changed engulfed it / gasoline but this gas is steam / so i let off sped off even with gas lean / $\mathrm{i}$ dream on the road swerve nerves get cold / with eyes closed no rose whose hand do i hold / the pain's like every single day like / he can't change like what should he gain like / life is like this life is like this / pain is like this you gotta fight this / the pain's like every single day like / he can't change like what should be gain like / life is like this life is like this / pain is like this you gotta fight this / momma coma damn drama drown her / not tryin' to be someone ya don't honour / loner in the desert my sweat pour colder like / moaner in reunion communion soldier like / mould her self own way so i stay this / delay the pay weigh see the light the day is / dark total eclipse the sun's movin' over / like the moon's overweight wait moon's over shoulders / look back back eyes start to glisten / fairy tale endin' ya see i'm still wishin' / missin' decide override the time is / shine lit i get left behind i didn't / i wouldn't couldn't with this tale ambiguous / rid of this gettin' this both contiguous / very close yes but $\mathbf{i}$ gotta separate it / the walkin' talkin' stalkin' $i$ hate it / the pain's like every single day like / he can't change like what should he gain like / life is like this life is like this / pain is like this you gotta fight this / the pain's like every single day like / he can't change like what should he gain like / life is like this life is like this / pain is like this you gotta fight this / the pain's like every single day like / he can't change like what should he 
gain like / life is like this life is like this / pain is like this you gotta fight this / the pain's like every single day like / he can't change like what should he gain like / life is like this life is like this / pain is like this you gotta fight this

\section{Appendix 3.4 \\ "it's ok"}

love me above me tryin' hard it's / lyrically handsome spit oh my God it's / please lord now i'm down on my knees / battlin' the devils evils so i'm hopin' that he sees / these men dyin' fight inside and / out and spoutin' na na now we gonna ride i got it live and / findin' now i finally feel / that it's ok and it's ok for real it's / the deal cards out on the table like the words shoot / out the mouth spoutin' flush like the same suit / love me above me proud or speak ugly / 'least u feel the feelin' like ya touched me / never ever budge me never ever clutch me / never ever ever ever the lovely / smugly emcee believe me when i spray / it's ok and what i'm tryin' to say is like <hook (sample)> love her if this is it it's god's will / fillin' askin' waitin' sleep deep until / the risin' beautiful around the sound it's / cliché i say but profound it's / wanna go against this take on they say / the world is blindin' with that he say she say / we play the game now again and again / but it's ok cos it's the god-send $i$ / spend before self try to be a good man / never ran plan from the understand / i'm tryin' to do me but all i see's you / beam through myself tryin' to please u / love her speakin' of her like a dove her / no one above her sky like i fly were / again sayin' this now i know / it's ok and what i'm tryin to show is like <hook (sample)> love it son wanna talk take on this the beat / the basics cravin' freak speech so sweet / cats can't catch up cats can't catch up / wanna talk more so your girl get snatched up / the nicest priceless get ya cash up / the night is mine so get ya flash up / stashed up in my memory i see / it's ok now who i wanna be / love me write me incite to fight me / fright me might be but never like me / hate me take me rite to the grave he / shaky wake me if this my fate be / late he to the finish line but still / the journey's more why i catch a chill / for real like psst psst whisperin' i'm tellin' em / it's ok how my words are fellin' em like <hook (sample)> love me tight the flow thru the nightly / right he nicely flow thru the spite be / hate me fake me so that the day be / breaking making flow thru the aching / love it or leave it now i really really mean it / seen it fiend it wanna be it wanna free it wanna clean it / hate it on the dream on the mind on the line / but it's ok how i'm keepin' on my rhyme like <hook (sample)>

\section{Appendix 3.5 \\ "combat jack"}

<"kids this is an example of satire of parody please use caution"> / rockin" army fatigues with a combat cap / spit combat raps and all y'all can't combat that / it's combat jack right for the jugular when i'm rhymin' / goin' for blood like when i hit these chicks' hymen / not even tryin' just flash the watch or the necklace / bracelet money clip whip i'm driving reckless / so check this should i push the benz or the lexus / either one'll get me all up in her solar plexus / can't hex this my voodoo'll leave ya whole crew / chokin' on they phlegm 'til they face turn blue / they eyes askew gotta do what $i$ do / new outfit everyday stayin' dipped like fondue / i ask you don't you want what i got / off one single that's hot talkin' 'bout dudes i shot / and bein' on lock though i never did and really wasn't / but once had a friend whose friend's friend's cousin's cousin / was once in for a dozen or two dozen or was it half a dozen / shouldn't say shit but this henney got me buzzin' $/<\mathrm{i}$ show you how to do this son $>/<\mathrm{i}$ show you how to do this 
son> / i don't need a hook $i$ got the whole look / combat jack with a rep that got 'em shook / got 'em took all these kids is buyin' my cd / they all wanna be me lifestyle of an emcee / don't need a hook $i$ got the whole look / combat jack with a rep that got 'em shook / got 'em took all these kids is buyin' my cd / they all wanna be me lifestyle of an emcee / strictly money over bitches livin' the thugs life / stuck in the game but can't complain 'bout all the riches i've touched/plus the chicks i've fucked would just drive you guys nuts / they line-up in handcuffs because of the size of my nuts / so hide when $i$ bust $i$ leave ya whole bust wetted / dedicated to the fans with a crush on johnny freddy / packin' a long machete along with a nine / $i$ not only sell records but also drugs as a nine-to-five / drive the livest ride watch my jewelry shine / the block's mine got it locked in my back pocket the cops cruise right by / got dimes on my arms who roll blunts for me / wanna be employee of the month come run some keys / the lifestyle of an emcee damn sure is tryin'/ photoshoots studio booths twenty-four-seven profilin' / sex drugs and violence with eyes red and droopin' eyelids /i'm ridin' sittin' on chrome blindin'/ forget nice rhymes what $i$ lack in cake i make up for in ice and / don't stress 'bout been tight man ive got the look / < i show you how to do this son $>/<\mathbf{i}$ show you how to do this son $>/ \mathbf{i}$ don't need a hook i got the whole look / combat jack with a rep that got 'em shook / got 'em took all these kids is buyin' my cd / they all wanna be me lifestyle of an emcee / don't need a hook i got the whole look / combat jack with a rep that got 'em shook / got 'em took all these kids is buyin' my cd/they all wanna be me lifestyle of an emcee / makin' this dough and flippin' these flows like kilos / tote more guns than g.i. joes / smackin' hoes plush livin' is a must gotta bust / two guns and one cock pull out without a fuss / 'cause i lust for money power in my way and $i$ devour / anyone jack take ya life in rush hour / emcees cower "cause they know that on the mic i'm gifted / roll up these lyrics 'cause my rhymes'll get you lifted / and ripped kid like combat always wasted / stumblin' around with a gun on my waist and / a vest on my chest so many kids i gotta guess / baby mama drama from the east to the west / suckin' on breasts only way i can ever sleep / so these broads know more than my rhymes hit deep / when i reap rewards of peddlin' to these dumb fans / give a fuck 'bout you 'cause worth measured in soundscans / like spiderman jack weave a tangled web / already got flow better hope my lyrics ebb / <i show you how to do this son $>/<i$ show you how to do this son $>$ / i don't need a hook i got the whole look / combat jack with a rep that got 'em shook / got' em took all these kids is buyin' my cd / they all wanna be me lifestyle of an emcee / don't need a hook i got the whole look / combat jack with a rep that got 'em shook / got 'em took all these kids is buyin' my cd / they all wanna be me lifestyle of an emcee

\section{Appendix 3.6 \\ "my club song"}

this an obvious shot aim for the radio / here we go kiddin' tho hear me in stereo / scenario me and this beat who's killin' it / if the dancefloor's not packed who's fillin' it / i'm feelin' it like sendin' a tingle down ya spine / $<30$ seconds gone by $>$ but $i$ just started my rhyme / gotta fit in chicks this jewelry money / cars and clothes and some shit that's funny / i'ma just do me on your campus got a backpack / schemin' tryin' to take over the world with chuck mac / dreamin' got 'em all noddin' they heads the club packed / screamin' when my track comes on is how they react / steamin' hot girls givin' they all / liks ya lips and get ya back up off the wall / hope you get it get it get it <get it get it> / mix like tanq and tonic on it how i lit it / this my club song three minutes to kill it / if the dancefloor's not packed who fills it / insert here $r$. kelly or ashanti / nate dogg pharrell lil jon beyonce / this my club song three minutes to kill it / if the dancefloor's not packed who fills it / insert here r. kelly or ashanti / nate dogg pharrell lil jon beyonce / not commercial but i'm strivin' 2 reach ya / lyrics hook now check out the feature / <goin' 'gainst me and cash your luck's tough / if the dancefloor's not packed we 're fillin' it up> / wait hold-up 
shit now that's enough / only a minute-and-a-half left to show my stuff / rough make ya cheeks puff when i tap the jaw / of these emcees spittin' like blah blah blah / with all that rah rah rah ya just playin' yaself / see me i'm startin' to heat up watch the microphone melt / $i$ dealt and felt no blows 'cause i slipped your $\mathrm{jab} / \mathrm{bob}$ and weave through the beat with this gift for gab / i am no fad check watch the speakers explode / clubs chargin' me with arson for the way that i flowed / download these lyrics 'cause my voice vital / cut paste put in a file and save as your idol / this my club song three minutes to kill it / if the dancefloor's not packed who fills it / insert here $r$. kelly or ashanti / nate dogg pharrell lil jon beyonce / this my club song three minutes to kill it / if the dancefloor's not packed who fills it / insert here r. kelly or ashanti / nate dogg pharrell lil jon beyonce / dudes "break ya" neck girls "make it clap" / gimme "one more chance" spit "machine gun funk" raps / tryin' to "hypnotize" y'all i ain't "frontin"" / no "superthug" but rhyme "grimey" like it's "nothin" / i'ma show you somethin' you "can't deny it" / look "right thurr" they startin' a riot / you should try it everybody here "tipsy" / got "bootylicious" chicks that shakin' they hips / track makin' 'em flip i like "the way you move" / "bad boy for life" spittin' shit with attitude / not tryin' be rude but hon "back that azz up" / be my "ms. fat booty" you're makin' my soldier "stand up" / this my club cut "party and bullshit" / "get your freak on" "sock it 2 me" quick / hit like "in da club" so go shorty start singin" / this the same beat that sound when your celly starts ringin' / this my club song three minutes to kill it / if the dancefloor's not packed who fills it / insert here $r$. kelly or ashanti / nate dogg pharrell lil jon beyonce / this my club song three minutes to kill it / if the dancefloor's not packed who fills it / insert here $r$. kelly or ashanti / nate dogg pharrell lil jon beyonce

\section{Appendix 3.7}

"Hip Hop is dead"

wha' what the who's knocking at this hour / wake me outta my sleep / and shit then he just gonna drive off / what the what's this / pop hour is hid as $i$ deep / but what does it mean / it looks like one of the anagrams / pop hour is hid as $i$ deep / but what does it / oh shit / Hip Hop is dead they said locked up / Hip Hop is dead they said locked up / Hip Hop is dead they said locked up / free Hip Hop rise up / Hip Hop is dead they said locked up / Hip Hop is dead they said locked up / Hip Hop is dead they said locked up / free Hip Hop rise up / a bold revelation quick flip the code it's / throwin' on my clothes $\mathrm{i}$ ' $\mathrm{m}$ all over the road lit / behold the spill the spot the skills unlock / $\mathrm{i}$ son eternal bang like g-spot / hang in t-dot got got i'm in shock / had my eyes locked all these years on the prize / dark skies shiverin' with fear near tears how can i rise / complicate the path throw off the spies / why $i$ communicated through my brainwaves / track back all of the dark nights $\mathrm{i}$ gave / krs chuck $\mathrm{d}$ been like they seen me / tu pac and biggie seem like a dream be / mos def talib kweli mean i'm leanin' / converse with immerse with knowledge from all / so when i flip these bars i can see from afar / scarred brain sonic balcony built on stars and now / Hip Hop is dead they said locked up / Hip Hop is dead they said locked up / Hip Hop is dead they said locked up / free Hip Hop rise up / Hip Hop is dead they said locked up / Hip Hop is dead they said locked up / Hip Hop is dead they said locked up / free Hip Hop rise up / but why'd they put in code my flow flip / probably in case $i$ wasn't home alone trip / got me in the zone got the beat $c d$ on blast / church make the sign of the cross as i pass / rehearse curse a verse i been workin' on / but what's the point now that Hip Hop is gone / silence but why'd they summon me / a backpack-wearin' story-tellin' emcee / thinkin' why could it be i don't see / what is it they want with me they hauntin' me / needin' speed now for all that i'm worth / everything flashback like my breach birth / board a plane it's it's must be insane it's / can't be be then it starts to rain it's / feelin' grounded while i'm in the sky / if Hip Hop's dead then $\mathrm{i}$ just might die how is it / Hip Hop is dead they said locked up / Hip Hop is dead they 
said locked up / Hip Hop is dead they said locked up / free Hip Hop rise up / Hip Hop is dead they said locked up / Hip Hop is dead they said locked up / Hip Hop is dead they said locked up / free Hip Hop rise up / arrive at my destination spit the password / walk in and the scene's absurd / grown men cryin' i'm just tryin' / to fathom but i'm feelin' like dyin'/ intricately can't get with it be- / side the coffin fire lit within me / walkin-up lookin' at faces sullen / my feelings dull then all of a sudden $/<$ flash $>$ the spark slice the dark / standin' in the middle of the circle hark / the angel like gabriel with sangreal / they all start to spit the hook now the realest / feel this how i'm supposed to closer / fuck you up quick in ya range rover / secret society they just tryin' me / all along but it's a tellin' sign you see / Hip Hop is dead they said locked up / Hip Hop is dead they said locked up / Hip Hop is dead they said locked up / free Hip Hop rise up / Hip Hop is dead they said locked up / Hip Hop is dead they said locked up / Hip Hop is dead they said locked up / free Hip Hop rise up / all through this signs ominous / but now i'm bombin' this cos i'm fond of this / i'm on all this i'ma stretch out this / limitless flippin' like a switch / but which i be growin' like ivy / poisonous coursin' through these veins like i.v. / o-r-a-c-i-o-u-s / i voracious focused influence / don't stand clueless power of the music / move it do it like i'ma lose it / use it advantageous positive / fm radio station's all on it / no calmin' it no singin' along it with it / ancestors always comin' along with it / circle ceremony center disciple / all anointed or fall like cairo / i know namin' sacred rite / like cashtro hop now i'm claimin' tonite / it's like control the mic like the son is the art / in the studio this this this how i start / Hip Hop is dead they said locked up / Hip Hop is dead they said locked up / Hip Hop is dead they said locked up / free Hip Hop rise up / Hip Hop is dead they said locked up / Hip Hop is dead they said locked up / Hip Hop is dead they said locked up / free Hip Hop rise up / free Hip Hop free Hip Hop / free Hip Hop free Hip Hop / free Hip Hop free Hip Hop / free Hip Hop free Hip Hop / free Hip Hop free Hip Hop / free Hip Hop free Hip Hop / free Hip Hop free Hip Hop / free Hip Hop free Hip Hop / free Hip Hop free Hip Hop

\section{Appendix 3.8 \\ "razzle dazzle"}

this is all like a bad dream / where am $i$ / rise from the dead flip-out now these words be / grippin" 'em splittin' "em break spit absurdly / personality turns multifarious / the scariest from a rap that's schizophrenious / ...induce psychosis / misdiagnosis means bigger doses / <misdiagnosis means> there's cosmic forces / of course this courses veins ferocious / <of course this courses $>$ the planets collide / clash and divide chaos worldwide / <clash and divide this $>$ this homeostasis / voracious spit out like these black hole places / $<i$ face this take this $>$ the one satanic manic contagious psychosomatic / < $i$ 'm frantic antics $>$ neurosis again / prognosis his hallucinogen /...razzle dazzle / ...razzle dazzle / ...never cease / prose beats stalk streets kill the beasts /...razzle dazzle / ...razzle dazzle / ...never cease / prose beats stalk streets kill the beasts / now the chaos ensues all around me i'm flounderin' / head in an ocean of red now astoundin' / massacre in one second only the few / but no set number so you wonder if it's you / and you knew that answer now the torture horrendous / feel the pain like the rhyme i tame slain tremendous / stupendous wonder and awe what they saw / when the rapture snatch ya tongue out ya jaw / ...razzle dazzle / ...razzle dazzle / ...never cease / prose beats stalk streets kill the beasts /...razzle dazzle / ... razzle dazzle / ...never cease / prose beats stalk streets kill the beasts / ...apostasy / head of the state fate theocracy / <can't talk or see> this sense perception / weapon lacks in cathedrals crept in / <slept in wept in> snatch your aura / look inside the deep dark halls of horror / <no tomorrow> internally screamin' / seemin' in the distance light gleamin' / <what you meanin'> feel delusion / illusion ensuin' mass confusion / <includin' excludin' $>$ the stars and heavens / prophet on it seal the $7^{\text {th }} / \ldots 666 /$ now there's 5 sins all 4 kicks / kick 3 kings and 2 many things / 1 time pick-up the line when i ring / ...razzle 
dazzle / ...razzle dazzle / ...never cease / prose beats stalk streets kill the beasts /...razzle dazzle / ...razzle dazzle / ...never cease / prose beats stalk streets kill the beasts / i gotta wake up...

Appendix 3.9

"out the box"

what's goin' on.. yeah it's the other-wordly emcee from another planet / we have now abducted you in and are taking you in for study and training / check it out / extraterrestrial messagin' a shuttle bust ya bubble out the rubble it is the non-subtle and a / can $u$ do this <here we go> knock 'em out... / kid planned it control the planets and suns / cash flow over ya head like condoms / 'cause i son so they crucifyin' me / sayin' this the messiah verse lord have mercy / the wordy son just battle the mos high / jesus christ stepped up and son could just tie / but i'm not tryin' 2 cure no dead eyes / in fact they can't see me still i'm on the rise / like this my resurrection and $i$ should mention / my ascension so u pay attention / erection flow 'cause "tro go all night / <yeah right> with a rhyme with a chick that bites and / <that's tight> son so i say it again / who planned it control the planets and then / and when i'm over ya head like these thorns / like a crown of 'cause y'all get ya heads torn / knock 'em out the box cash knock 'em out cash / knock' 'em out the box cash knock 'em out cash / knock'em knock'em knock 'em knock 'em knock 'em knock 'em / knock 'em knock 'em knock 'em knock 'em knock 'em knock 'em / knock' 'em out the box cash knock 'em out cash / knock' em out the box cash knock 'em out cash / knock 'em knock 'em knock 'em knock 'em knock 'em knock 'em / knock 'em knock 'em knock 'em knock 'em knock'em knock'em / proud not arrogant flip the power it's / knock 'em out the box soul son devours it's / flames'll shower it's 1-l-like fire / or electrical shockwaves and 1-1-live wires / like them skydivers spirit when you hear it now / check all these cowards runnin' how they fear it <wow> / rock i mean it make 'em fiend it / deal this spit and flip back to egypt / <oh shit> roadblock they can't detour me / when i grind my mandate they all gonna feel me / layer like we do in the north with overcoats / ch-ch-chatterbox they over-quote-d / sugarcoated wrote the beat eerie / float over into your throat human theory / knock "em out the box peacock feathers spreadin' / blue green yellow purple orange red and / iridescent this song of solomon / knock 'em out the box so they always followin' / always swallowin' this dust in my wake / with memories see me eyes awake / i q-q-quake keep jumpin' these caverns / leap over taverns demons battlin' / shake like a rattle riddle keep hittin' em / right in the heart peepin' bodies hidden in / always riddin' 'em of wack material / possess the best no rest less imperial / e-e-ethereal i stalk the pavement / mind be outsmart wit enslavement / entertainment nah this a baptism / still with flames r-r-r-raptism / another one still reflects like a prism / too much disrespect they won't miss 'em / p-p-pick 'em pick me this time / when i knock 'em out the box and i'm writin' a rhyme / when i'm on the grind grimey like a mudhole / stomp through knock 'em out me and my flow / knock 'em out the box cash knock 'em out cash / knock 'em out the box cash knock' em out cash / knock' em knock 'em knock 'em knock'em knock'em knock'em / knock'em knock 'em knock 'em knock'em knock 'em knock' em / knock' 'em out the box cash knock' em out cash / knock' em out the box cash knock 'em out cash / knock 'em knock 'em knock'em knock'em knock'em knock'em / knock 'em knock 'em knock 'em knock'em knock 'em knock 'em / AND yeah we did it yes we did now take this back to your own planet and ran it here we go 


\section{Appendix 3.10 \\ "perfume"}

$<i$ know you / you know me / we can flow together / naturally > / how many emcees will dismiss / before somebody says yo i'm fuckin' with chris / this c-a-s-h-t-r-o / it's the real fuckas fake like video hoes / so flow's when he bust he bust ridiculous / see what fuck's tryin' to hear for a cuss / sayin' what's the name like what's his chain like / change the game change the fame the plane's like / balcony level feelin' the higher treble / in trouble this decibel double hubble a rebel / it is the extraterrestrial messagin' you from a shuttle / bust ya bubble out the rubble it is the non-subtle and a / matter-of-fact this the point where i'm from <check> / isaiah 61:1 i son <check > / track-slayer ridin' the beat 'til it's done <check> / my prayer seein' the light so i run <check> / try to bottle up my spirit <perfume> / full moon dawn soon in tune / audio track-list try to black-list / audio track-list try to black-list / try to bottle up my spirit <perfume> / full moon dawn soon in tune / audio track-list try to black-list / audio track-list try to black-list / had this never settle unsettle / got a rap so clever jack-it like full metal / indelible incredible always restless / wordsmith make "em forget 'bout they guest list / ...runnin' drill after drill / been fly for so long caught the flu now i'm ill / i spill out how eye done seen some things you can't phase / spill out how my eye gleam i dream amaze / try to bottle up my spirit <perfume> / full moon dawn soon in tune / audio track-list try to black-list / audio track-list try to black-list / try to bottle up my spirit <perfume> / full moon dawn soon in tune / audio track-list try to black-list / audio track-list try to black-list / reach 'em preach like an evangelist <check> / revel seein' devils think they combat this <check > / how many emcees must get dissed <check> / <audio track-list try to black-list> / pre-existin' wind-up missin' / snake bite hissin' reminiscin' / thinkin' freeze content / medium the mandate $i$ represented / reinvent re-repent the presented / unwrapped adapted the torment get / sent to the edge on my rap summit / all these rappers screamin' when they plummet / balcony level shit we gon' run it / balcony level shit we gon' run it / i'm a heavy hitter all ya rhymes light / got head-bangin' dudes rockin' like < fuckin' right>/ try to bottle up my spirit <perfume> / full moon dawn soon in tune / audio track-list try to black-list / audio track-list try to black-list / try to bottle up my spirit <perfume> / full moon dawn soon in tune / audio track-list try to black-list / audio track-list try to black-list

\section{Appendix 3.11 \\ "american justice I"}

i'm universal i see through your universals / freedom liberty God i get hurt still / learnin' ya dream earnin' three times more now / an individual you think i'm learnin' much more how / i turned my back on the fields that raised me / city's bright lights done made my mind crazy / forsaken ya promises hollow / family of five urban squalor wallow / i'm the poster-boy for globalization / no sounds and drowns in one big nation / you gotta rise and breathe above modernity / we're gaspin' graspin' it's damned eternity now / willful ignorance check reality / 'cause millions a day be facin' down mortality / you have and we have not / and if we had too think how the earth would rot / this is the battle speed's priority / fate on the line see the vast majority / face ya global village is a slum by choice / so many languages but just one voice / american justice got us seein' star clusters / gotta fight up all the might that ya can muster / american justice got us seein' star clusters / star clusters... 


\section{Appendix 3.12 \\ "i eternal"}

$<i$ eternal > / kick it it's afflicted kids hot sweat beads tricklin' / utter chaos poor man finds a nickel / it's the ficklest heads this my lime green stream and / he tryin' to be a cog in the machine for his queen / but his dreams overcome now his thoughts are overrun / searchin' for a purpose so they hurt us overdone / why you tryin' push he see he's close to the edge / back against the wall he lookin' out over the ledge / but he pledge he push he push for his family / clutch the heart make the art deep pain badly / affectin' the psyche descent he repented / tryin' to make your money well spent this his eighty- / four percent torment finally addressed i am / blessed her smooth brown skin got him cryin' / over demons from the past look into the looking glass / at long last he passed the point this no return / feel the burn in his stomach why she done it / why he gotta ask these questions / it's his olive-skinned complexion reflection this a resurrection / a spark of the divine when he rhyme lime is passion / clashin' too many strong wills / look back on that moment and he always catch chills / "cause it drills home how he feels he's a speck / overwhelmed by a starry host on his deck / now dust becomes thick now the universe is spinnin' / vision vision's blurred blurred sight and sense are dimmin' / like swimmin' in a lake with the stars overhead / midnight for this he bled feel a moonlight / thread pierce your soul this a one drummer drummin' / like uh uh solitary how he comin' / see the hand see the reach understand now he preach / from the pulpit pointin' out the culprit but / they want it so he haunt it this the funeral procession / confession expression impression no question / this nocturnal internal this his journal / because i eternal / this nocturnal internal this my journal / because i eternal / relate to the hazard she hazard a guess near death / body mind fail ail God bless deep breath / this is not a test this is life right / a single tear streams down her check to end the fight / incite the madness if you had this / feel the pain inside and just grab this she scribble / on her pad this began this now her plan is / reminisce if she run this she ran this / they can't stand this is what they hear / when she up in her room while they drinkin' they draft beer / she is a gas sphere a star from afar / you see her mind bendin' they cell bars / she ask for you by my side and there you are / like a minstrel walkin' 'round with his guitar / $\mathrm{i}$ are i be $\mathrm{i}$ am this rhyme manifested / rise and fall like her chest you can't guess / what anyone's gone through she been through / begin within you spin win she do / she knew word is flesh so flesh shed invented / heaven-sent circumvent the tormented / blood pressure buildin'-up she's near death / only twenty-three years-old and still she's near death / she went and ran writin' through the jungle the desert / she went and ran writin' through the past the present / no hesitation spittin' truth in the booth / man gunned down and a baby lose a tooth / both fightin' for that freedom i read him i can't see him / $\mathrm{i}$ weed 'em i lead 'em and with this verse i try to breed 'em / exceed 'em one time this my intent negative / enlighten positive representin' what i'm doin' / talkin' to gandhi talkin' to john paul / the second talk to john wesley talk to / medgar evers relate see the path she pass / now alas surpass this the glass the gas / this nocturnal internal this his journal / because $i$ eternal / this nocturnal internal this her journal / because $i$ eternal / this nocturnal internal this my journal / because i eternal 


\section{Appendix 3.13 \\ "american justice II"}

welcome to the home of the brave and the land of the free / where we spend more on lawn care in a year than a third world country's gdp / where we give new meanin' to keepin' up one's own backyard / while droppin' napalm abroad on so-called gomorrahans and sodomites/slack-jawed troglodytes keep on gettin' applause / for two minute long bomb runs eclipsin' the dawn / what's wrong we turn right we turn rites to wrongs / but strong shines my light when the night has fallen / $i$ long to strike horizons with unbridled force / the fight is on the drive comes from an unrivaled source / just like the fire from a torch $i$ bring light to the course / takin' the path less traveled to bring the battle to the north / like confederate soldiers on the front lines of dixie / backed by bigotry worried 'bout what size they dicks be / quickly read the signs the stripes hypnotize / while the colours blind ya eyes and the stars leave ya tipsy / $\mathrm{i}$ got mixed feelings dealin' with my dark side / if evil comes from the devil then my leaders have tricked me / tried to make me turn a blind eye to the apartheid/when it's right under my nose what they think this is $1860 /$ it makes me sick to my gut $i$ can't stomach it / i need a sip from the cup but there's no blood in it / so i turn nicks into cuts like the government / $i$ need to get back in touch with God's covenant / as we milk the cow everyone is incensed / entrenched in the words comin' from my print press / four editions daily got you up to the minute / knees bucklin' from the story my uncle charlie is spinnin' / extra extra read all about it / the ballots have been counted come find out who's next to be in power / next to flex and scour in the name of protectin' cowards / makin' history projectin' this could be our finest hour / choppin' necks and takin' heads to fill with dirt and flowers / then let the sun shine in unobscured by all of the towers / up for bringin' down the infrastructure fuck the brotherhood / of mother-truckers their days of movin' 'round are done / movin' in to touch ya my words empower sons to do bomb runs / on their folks this is a lump in the throat abduction / always up to somethin' high on uppers and dope / they're up in smoke been dusted off by the thing they put they trust in / american justice got us seein' star clusters / gotta fight up all the might that ya can muster / heavy on the thrusters and never look back jack / put back that counterproductive dust buster / while millions suffer we relax on luxury's lap / kickin' back dreamin' of new things to lust for / the gap between wants and need is more than you think / throw in the second law of thermodynamics entropy / always increases meanin' things / will only get worse before they're gonna get better / so better end the greed that's needless / that's the reason the middle east is so full of hot-headed go-getters / but they still don't get it man don't need the weatherman / to show ya the direction that the wind is headed in / $\mathrm{i}$ got a better plan take ya finger and wet it / hold it up high to the heavens and let it show ya what's greater and lesser than / the quest of man goes on and on / like the cup drought in this town man it's wrong / american justice got us seein' star clusters / gotta fight up all the might that ya can muster / heavy on the thrusters and never look back jack / put back that counter-productive dust buster

\section{Appendix 3.14 \\ "and it goes like this..."}

yeah $\mathrm{i}$ love this beat chuck / yeah? yes yes / well what are you gonna do with it? / yo i'ma tell this story $\mathrm{i}$ wrote last nite / do it cash /... and it goes like this /...and it goes like this / ...and it goes like this /... and it goes like this / my man step out the crib hat tilted to the left / crisp jeans new tee think he hot to def / walk down the street life real sweet / got that swagger clean kicks with a hop in his feet / see a homeless dude and give him all the money / out the pocket just miss the bus so decide / that he'll just walk it <walk it?> now he got no money / one more block and he sees this honey / <honey?> yeah a fit girl at the light / body tight but covered so her mind right / she say "do you know the way to the record 
shop?" / he say "yeah "cause i go there a lot" / she say "well i'm new in town" / and he say "well i'd love to show you around" / ... and it goes like this / ... and it goes like this / ...and it goes like this / ...and it goes like this / she say "hey do you like hip-hop?" / he say "yeah girl $i$ like it a lot / in fact speakin' of the devil / i got this crew called balcony level / we're doin' a show tonite / i'd love to take you if it'd be alright" / "wow now you're quick like that / i know your smile" like she wanna smash that / at nite they walk to the show / she say "can't wait to hear you flow" / all set she lovin' the music / he gets off stage and she starts to lose it / "love the performance" start to converse / the whole night flows just like my verse / and from there not much to be said / it goes on and on just like my pencil lead / ....and it goes like this / are you kidding? and it goes like this / what do you mean? and it goes like this / all 'cause of one smile? and it goes like this / that's corny and it goes like this /ok ok and it goes like this / this the alternate version and it goes like this / ....and it goes like this / my man step out the crib hat titled to the right / mean mug some shit look he want to start a fight / flip the celly call his boy with the range rover / see a homeless dude but he steps right over / <right over?> yeah 'cause he want to keep his money / got a show tonite wanna get a fine honey / <a honey?> yeah a girl with a body tight / queen at the light is just another sight /... and it goes like this / alright $i$ get it man and it goes like this / and it goes like this / and it goes like this / ...and it goes like this / ... and it goes like this / ... and it goes like this $/ \ldots$ and it goes like this...

\section{Appendix 3.15 "free-thought"}

y'all lace my name fame like son can't spit / i fly high get like a hot-boxed cock pit / words get though i'm focused sir / why i'm lifted you try defer / this dream word still hook line sinker / how you keep it distill this thinker / drink of madness with bottles of gin get / again and again with shots next to kin with / kidney stones he be like 'cause he stoppin' / everything urine get it now he coppin' / everything u got the one son dramatic / fuckin'-up ya airwaves like it's static / erratic addict who this gone drastic / cannibal instinct the mandible's intrinsic / just eat try me catch this food poison / noise in my ear i am ya girl's toy and / flip coin like tail i call head quick / baritone monotone i bald head slick wit / who spit like full clip shit you like half this / style's like s-s-a y'all ass backwards / style like what he say y'all can't have this / style like where he lay y'all can't stab this / i'm just tellin' who where and why / what they do look again when how in the sky / $\mathrm{i}$ try my dye like i mediterranean / mind frame larger than the orbits sun blazin' 'em / think your smart please renaissance it starts / reconnaissance sparks clash divide art it's the facade / u wastin' tracin' 'em i'm tastin' 'em / with flavour like monosodium my mono-pseudonym/through with 'em how they call me defiant / through with 'em now they want me defiant / this chris rip like freethought flow through / rhyme supersonic womb to tomb like 12 / snafu snatch up ya view leave no clue / free-thought flow through tape letter screw / you knew you do so you preach prophetic / alphabetic arithmetic flow frenetic / anesthetic for the weak flow pathetic / pops taught me how to be a man consider it genetic / energetic athletic spit ascetic / sick a medic just ran to get another medic / so i set it get it feelin' how i'm fiendin' / christopher christ-like demons scheme on daydreamin' / meanin' 'gain this free-thought flow though / rhyme supsersonic tomb to womb like 1212 /...and that's $i t /$...and that's all $i$ got 


\section{Appendix 3.16 \\ "conclusion: more power"}

they didn't think i'd hit 'em like this / cash hop / y'all cats can't catch up / whoo! / this is how i'm endin' it / it's over it's through / whoo! / cats wanna talk shit to me for spittin' like / cash wanna hawk this i'ma bet on my life / who half as nice as i grab ya spite like / soda pop bottle body hottie cherry cola ripe <whoo! $>$ / carbonation bustin' like it's him / contents checkin' like a chin shakin' like a tin / can can can the plan is / kick shit all over the track now i'm lappin / so look behind the rhyme find i'm / grind this time after time / line feelin' like a legend this lore and / rap jim morrison kick in ya door and / who's scorin' like i'm jordan / get open like these or and / what you think off the balcony spittin' $i$ / hang 'em like these nuts when i'm shittin' why / I endeavour spit so clever / leave they heads sweller easier to sever / i get more power i get more power / i get more power i get more power / i endeavour spit so clever/ leave they heads sweller easier to sever / $i$ get more power $i$ get more power / $i$ get more power $i$ get... / come catch the bass in ya ear these lyrical lacerations will slash you / into rations that could last us clear over a year / we eatin' good happily ever after with no cares so who cares / if we goin' nowhere man we eatin' we good /'cause i get more power off the cliques $i$ devour/my hands are red at the top and bottom of every hour / time to topple the tower i gotta get my fill / watch the blood spill and people scatter as $i$ blacken out the sun /'cause my vernacular stuns these wack rappers and renders them / utterly speechless with more reach than the teachings of jesus / preachin' to heathens my spree is never done / so everlastin' it's written in the book of revelations / go get lost in the devil's taste test son / a makeshift red rum mixed up with bedlam / so come get some <whoo!> you're dreamin' like alchemy / have your neck wrung and get hung from the balcony / $\mathbf{i}$ endeavour spit so clever / leave they heads sweller easier to sever / $i$ get more power $i$ get more power / i get more power i get more power / i endeavour spit so clever / leave they heads sweller easier to sever / $i$ get more power $i$ get more power / i get more power i get... / cashtro flow through smog and mist like / peace like two fingers or they wanted my fist like / up to the wrist so i gave 'em a hand like / clap but don't want that understand i / fam forever if devils can't damn me / janet's little boy's spirit but more manly / can he i wonder no man's put asunder / how i spit like tomorrow my last passed and under / yesterday got no beat i sway / but now by my side $i$ ride far away $i$ / see the light today this is a ray / $i$ say what $i$ say $i$ spray what $i$ spray $i$ / cashtro hop is the name i pray like / believe emcee's are god words are clay right / control the mic like friends be callin' me / by my surname a son an oddity / and this an odd project i project / these words revolutionize skies and concepts / and this an odd project i project / these words revolutionize skies and concepts / $\mathbf{i}$ endeavour spit so clever / leave they heads sweller easier to sever / i get more power $\mathbf{i}$ get more power / i get more power i get ... / i endeavour spit so clever / leave they heads sweller easier to sever / i get more power i get more power / i get more power i get more power

\section{Appendix 3.17 \\ "one day"}

two young boys sat on a cool day / tryin' to decide on a game they could play / they sat like this talking almost every day / for their friendship was all to both boys in his way / the first boy loved things far far away / and was all about music, film, acting in plays / his mind was focused on becoming one day / an actor or writer at night he would pray / "lord help me to realize my dreams take away / all roadblocks that stand before me everyday" / the other boy's mind could be easily swayed / for he sought popularity here now today / so when older boys stopped in a new chevrolet / smoking and drinking all in a display / inviting the two to join their foray / the second boy jumped up quick and did say / "yes yes i'll be coming 
your way / yes yes i'll be coming your way / yes yes i'll be coming your way / yes yes i'll be coming your way" / the first boy thought and then pondered that day / though the older boys showed that they hated delay / he knew that these boys could lead him astray / for they got high so often their minds slipped away / still hanging with them could make him portray / he was down to his first crush a girl named renee / the first boy thought and then ventured to say / " $\mathrm{i}$ think the two of us will stay here to play / we're not into all that now please go away / we're not into all that now please go away / we're not into all that now please go away / we're not into all that, now please go away" / these words made the second boy's face show dismay / for he could not believe that his friend would just say / such things to the others and in his dismay / the second boy chose that he'd go anyway/ so then on from that day the two boys would not say / much to each other for both felt betrayed / once tight tight friends who talked everyday / now nearstrangers who rarely crossed ways / the first boy kept on day after day / and at eighteen wrote and directed a play / that day for the second boy marked his decay / he dropped out of school to his mother's dismay / hit after hit day after day / his soul grew more weary he wasted away / his skin turned gray and in disarray / he found himself living on the street one day / ten years later to that fateful day / the first boy started to star on broadway / the second boy called the first just to say / "good luck with everything this is your day / i was on the right way then i strayed / you took the right pathway and stayed" / and all the first boy could even say / was "you made your own decision on that day / $i$ can't help you anymore now please go away / i can't help you anymore now please go away / i can't help you anymore now please go away / i can't help you anymore now please go away" / the second boy cried and cried that day / and said i'm gonna tum around my life today / drug rehab had him on the right way / earned a degree by learning to obey / that everyday he'd work as hard on essay / as he would tryin' to treat people the right way / twenty years later from that fateful day / it was the first now in disarray / crowds no longer threw bouquets his way / he turned to alcohol to try and allay / some of the pain that he felt each day / more drinking led his wife to go away / she took the kids the cabriolet / and he had to live with that every single day / and he had to live with that every single day / and he had to live with that every single day / the first boy phoned his old friend just to say / he was sorry for what happened on that day / that the second boy called the first just to say / good look with everything this is your day / "i never ever should have treated you that way / now i know what it's like in disarray" / and without delay the first boy heard the second say / "i'll help get you back on your way / i'll help get you back on your way / i'll help get you back on your way" / and from that day "til the end of days / both boys treated each other the right way / both boys treated others the right way / all because of that one fateful day / one day... 


\section{WORKS CITED}

Anderson, Raymond Dennis Seymour. "Black Beats For One People: Causes and Effects of Identification with Hip-Hop Culture." Diss. Regent University, 2003.

Androutsopoulos, Jannis, and Arno Scholz . "Spaghetti Funk: Appropriations of Hip-Hop

Culture and Rap Music in Europe." Popular Music \& Society 26.4 (Winter 2003): 463479.

Baraka, Amiri. "The Language of Defiance." Black Issues Book Review 28 (Sep/Oct 2001): 28.

Barnwell, Lisa A. "The Multiple Performances of Identity Through Hip-Hop Culture: Relevance for Black Youth in the Canadian Context." Diss. University of Toronto, 2004.

Bertram, Dennison. "Czech Hip Republic Hop." New Presence: The Prague Journal of Central European Affairs (Spring 2003) 5.1: 42-43.

Bluher, Dominique. "Hip-Hop Cinema in France." Camera Obscura 16.46 (Jan 2001): 76-97. Brewster, Bill and Frank Broughton. Last Night a DJ Saved My Life: The History of the Disc Jockey. New York: Grove Press, 2000.

Cheeseman, Tom. "Hip Hop in Germany." Debatte: Review of Contemporary German Affairs 6.1 (May 1998): 191-214.

---. "Polyglot Politics: Hip Hop in Germany." Debatte: Review of Contemporary German Affairs 6.2 (Nov 1998): 191-214.

Clifford, James. The Predicament of Culture: Twentieth-Century Ethnography, Literature, and Ant. Cambridge, MA: Harvard UP, 1988.

Cutler, Cecilia Anne. "Crossing Over: White Youth, Hip-Hop and African American English." Diss. New York University, 2002. 
Dawson, Ashley. "'This is the Digital Underclass': Asian Dub Foundation and Hip-Hop Cosmopolitanism." Social Semiotics 12.1 (Apr 2002): 27-44.

Dyson, Michael Eric. "Foreword." Forman xi-xiv.

Elflein, Dietmar. "From Krauts with Attitudes to Turks with Attitudes: Some Aspects of HipHop History in Germany.” Popular Music 17.3 (Oct 1998): 255-265.

El-Tayeb, Fatima. "'If You Can't Pronounce My Name, You Can Just Call Me Pride': AfroGerman Activism, Gender and Hip Hop." Gender \& History 15.3 (Nov 2003) 460-486. Fenn, John, and Alex Perullo. "Language Choice and Hip Hop in Tanzania and Malawi." Popular Music \& Society 24.3 (Fall 2000): 73-93.

Fernandes, Sujatha. "Fear of a Black Nation: Local Rappers, Transnational Crossings, and State Power in Contemporary Cuba." Anthropological Quarterly 76.4 (Fall 2003): 575-608.

--. "Island Paradise, Revolutionary Utopia or Hustler's Haven? Consumerism and Socialism in Contemporary Cuban Rap." Journal of Latin American Cultural Studies (Travesia) 12.3 (Dec 2003): 359-375.

Fernando, S. H., Jr. "Back in the Day: 1975-1979." Light 13-15, 18-21.

Forman, Murray, and Mark Anthony Neal, eds. That's the Joint!: The Hip-Hop Studies Reader. New York: Routledge, 2004.

Fricke, Jim and Charlie Ahearn. Yes Yes Y'All: The Experience Music Project: Oral History of Hip-Hop's First Decade. Cambridge, MA: Da Capo Press, 2002.

Goffman, Erving. The Presentation of Self in Everyday Life. Garden City, New York: Doubleday Anchor Books, 1959.

Hendershott, Heidi A. "School of Rap: The Politics and Pedagogies of Rap Music." Diss. The Pennsylvania State University, 2004. 
Hochtritt, Lisa J. "Creating Meaning and Constructing Identity Through Collaborative Art Practices Among Urban Adolescents.” Diss. Columbia University Teachers College, 2004.

Krims, Adam. Rap Music and the Poetics of Identity. Cambridge, UK: Cambridge UP, 2000.

LaBennett, Oneka. "Consuming Identities: Consumption, Gender and Ethnicity Among West Indian Adolescents in Brooklyn." Diss. Harvard University, 2002.

Light, Alan, ed. The Vibe History of Hip Hop. New York: Three Rivers Press, 1999.

Liu, Catherine. "French Rap/MC Solaar." Sites: Journal of the Twentieth

Century/Contemporary French Studies 1.1 (Spring 1997): 327-332.

McLellan, Rory Duncan. "Styling Life: Race, Space, Consumption and the Problem of Immanent Soul.” Diss. University of Guelph, 2002.

Mitchell, Tony. "Doin' Damage in My Native Language: The Use of 'Resistance Vernaculars' in Hip Hop in France, Italy, and Aotearoa/New Zealand." Popular Music \& Society 24.3 (Fall 2000): 41-54.

Orlando, Valerie. "From Rap to Raî in the Mixing Bowl: Beur Hip-Hop Culture and Banlieue Cinema in Urban France." Journal of Popular Culture 36.3 (Winter 2003): 395-415.

Osumare, Halifu. "African Aesthetics, American Culture: Hip Hop in the Global Era." Diss. University of Hawaii, 1999.

Poteet, Morgan B. "Cultural Identity and Identity Performance Among Latino American Youths in Toronto." Diss. York University, 2002.

Prevos, Andre J.M.. "Hip-Hop, Rap, and Repression in France and the United States." Popular Music \& Society 22.2 (Summer 1998): 67-84. 
Rose, Tricia. "Black Noise: Rap Music and Black Cultural Resistance in Contemporary American Popular Culture.” Diss. Brown University, 1993.

--- Black Noise: Rap Music and Black Culture in Contemporary America. Hanover, NH:

University Press of New England, 1994.

Rutherford, Marc Allen. "Mass Media Framing of Hip-Hop Artists and Culture." Diss. West Virginia University, 2001.

Shapiro, Peter. Modulations: A History of Electronic Music: Throbbing Words on Sound. New York: Caipirinha Productions, 2000.

Shapiro, Roberta. "The Aesthetics of Institutionalization: Breakdancing in France." Journal of Arts Management. Law \& Society 33.4 (Winter 2004): 316-335.

Smith, William Earl. "Hip Hop as Performance and Ritual: A Biographical and Ethnomusicological Construction of a Washington D.C. Hip Hop Artist Named Priest Da Nomad." Diss. University of Maryland, 2003.

Smitherman, Geneva. Talkin and Testifyin: The Language of Black America. Boston:

Houghton Mifflin, 1977.

--. "The Chain Remain the Same': Communicative Practices in the Hip Hop Nation." Journal of Black Studies 28.1 (Sep 1997): 3-25.

--. Black Talk: Words and Phrases form the Hood to the Amen Corner. Boston: Houghton Mifflin, 1994.

Somers-Willett, Susan B. Anthony. "Authenticating Voices: Performance, Black Identity, and Slam Poetry." Diss. The University of Texas at Austin, 2003.

Szwed, John F. "The Real Old School." Light 3-11. 